\title{
Evolution of Banking Structure: Industrial Policy and Deregulation
}

\author{
by \\ Yoonhee Tina Chang \\ ESRC Centre for Competition Policy, University of East Anglia \\ CCP Working Paper 06-4
}

\begin{abstract}
This paper analyses the impact of various types of deregulation on banking industry structure. The empirical result is supported by evidence from Japan and Korea, which have undergone a substantial consolidation following a series of deregulation. The analysis is applied to a unique data set of the entire commercial banking sector in Japan and Korea, which covers both pre- and post- banking crisis periods. The paper also draws attention to the role of banking sector in the East Asian industrialisation, which influenced its idiosyncratic banking regulation and the evolution of the banking structure using the structure-performance relationship.
\end{abstract}

December 2005

JEL Classification: G21; G28 ; L13 ; L59

Keywords: Banking Structure, Deregulation, Industrial Policy

Acknowledgements:

I am grateful for encouragement and many helpful comments from Keith Cowling, Jeremy Smith. I also wish to thank Andrew Oswald, Alan Roe, Roger Sugden, Mike Waterson, Myrna Wooders, and seminar participants at University of Warwick, University of Birmingham, Australian National University - APSEG and RSPAS, the $6^{\text {th }}$ SMYE, EARIE 2001, and EUNIP2001 for helpful comments and discussions on previous versions of this paper. The support of the Economic and Social Research Council (UK) is gratefully acknowledged. All errors are mine.

Contact details:

y.chang@uea.ac.uk, ESRC Centre for Competition Policy, University of East Anglia, Norwich, NR4 7TJ, UK. www.ccp.uea.ac.uk t: +44 (0) 1603593715 f: + 44(0) 1603 591622

ISSN 1745-9648 


\section{Introduction}

Throughout the last decade, the East Asian banking industry has adopted a significantly more concentrated market structure. The number of banks in the region was substantially reduced via mergers and exits in the late 1990s. Japan has authorised only one new regional bank since 1976 whilst there were 5 large-scale mergers between nationwide banks and one revocation of the license in the 1990s. On the other hand, the banking structure in Korea took a slightly different path. Korea authorised 9 new nationwide banks and 3 transformations from specialty banks throughout the industrialisation in the 1980s and early 1990s. Then, Korea took a drastic turn with 9 mergers between nationwide banks and 4 mergers between regional banks. This wave of mergers and exits has halved the number of nationwide banks in Japan and Korea from its peak as shown in Table 1, and the market share of the larger banks has grown. One may argue that the Japanese and Korean banks made a radical move towards consolidation to deal with their respective economic and financial crises since the consolidation seems to coincide with the post-crises period as shown in Figures 3 and 4. Traditionally, one of the main roles of these East Asian banks was a means of supporting the real sector in the process of pursuing economic development. ${ }^{1}$ However, when the East Asian financial crises in 1997 triggered the restructuring process of many industrial sectors in the region, the banking sector appeared to be an industry where restructuring was most urgently and seriously required. The 1997 financial crisis in Asia renewed recognition of the significance of the banking industry and its importance to the overall economy.

Previous literature (Cerasi et al., 2002; Chiappori et al., 1995; Dewatripont and Maskin, 1995; Dewatripont and Tirole, 1993) on bank structure has primarily focused on the impact of exogenous change in regulation and the subsequent change in competition environment without any consideration of industrial policy. The industrial policy in East Asia, which dominated banking sector regulation, had the objective of encouraging industrial development in the region. Therefore, the competition environment in the East Asian banking should not be investigated independently of its industrial policy.

Banking regulation in Japan and Korea has included entry barriers, branching restrictions, and deposit rate ceilings. East Asian banking regulation was designed to facilitate the development of strategic industries as shown in Table 2. Japan and Korea have aimed to promote certain industries, which they believed to be strategically beneficial for the national economy. The target industries have varied from primary and light industries (food and textiles) in the 1950s and 1960s, to high-tech knowledge intensive industries in the 1990s. The deposit rate regulation, for instance, allowed banks to have access to cheap funding so that they could provide loans at lower rates to these strategic industries. With cheap funding via banks and with the help of government subsidies, the strategic industries could grow fast, generating supernormal profits and remained as high quality customers to banks. This kind of growth pattern continued in East Asia until they faced the recent economic crises.

Not only have Japan and Korea led the economic growth in East Asia, but also other East Asian countries have replicated many of the development patterns set by Japan and

\footnotetext{
${ }^{1}$ Kim (1999) claims one of the reasons for recent financial crisis in Korea is basic functions of the financial industry being neglected such as credit screening, which led to higher non performing loans.
} 
Korea. ${ }^{2}$ Moreover, the two countries have similarities in their industrial structure due to their strong trade networks. ${ }^{3}$ Since the modern banking system in Korea was established during the Japanese occupation, it seems natural that Korea followed the Japanese type of banking establishments. However, there is some evidence of divergence as well as convergence in terms of recent restructuring of the banking sector, especially with respect to adopting concentrated market structure as in Figures 3 to 6 . For instance, the Korean banking structure has consolidated more immediately and drastically after the 1997 Asian financial crisis. One the other hand, the Japanese banking structure has reacted to the economic crisis in the early $1990 \mathrm{~s}^{4}$ with some delays and the major banking consolidation took place only after 2000 with almost a decade delay. The difference in the restructuring is more notable when the two countries are compared in terms of regional banking as Japan does not appear to have implemented any measures for their regional banks.

The main emphasis of this paper is to identify the determinants of banking structure in East Asia using empirical data from Japan and Korea. The recent consolidation in East Asian banking will be assessed with respect to industrial policy and regulation. This paper also investigates the role of Japanese and Korean banks in their respective industrialisation processes and how the changes in regulation affected the evolution of the market structure based on the structure-performance relationship.

In section 2 reviewed the role of East Asian banks in industrialisation by comparing the evolution of the banking system with the country's macroeconomic position. The uniqueness of this approach lies in the sense of inter-industry comparison between financial and non-financial industries using an industrial organisational framework. It is important to note that financial and non-financial industries have different attributes and therefore, it is interesting to investigate how they have evolved together.

The consequences of the regulation and deregulation on entry, branching and deposit rates were empirically investigated. The different types of regulation and deregulation are defined and separately analysed from a country specific perspective. The relationship between concentration (Structure) and the degree of competition (Conduct) in Japan and Korea is examined. The effects of deregulation on the structure of the banking industry and the profitability (Performance) of banks are tested. The evolution of banking industry in the two countries is compared and shows evidence of divergence in the restructuring process of the banking sector between Japan and Korea.

\section{East Asian Banking and Industrialisation in Context}

In the post war period, East Asian Governments actively promoted heavy and chemical industries and some academics like Cho (1994) and Castley (1997) argued that the financial sector was lagging behind the fast-developing real sector. Moreover, the pattern of fast growth in the real sector and the lagging financial sector was common in

\footnotetext{
${ }^{2}$ World Bank data categorise Japan, Korea, China, Hong Kong, Indonesia, Malaysia, Philippines, Singapore and Thailand as East Asia. However, Japan and Korea dominated the regional economy and its growth representing 78-90\% of East Asian GNP (constant market price 1995, in US dollars) over the period 1960-1997. Their contribution to the regional growth has been more than $80 \%$, which fell down to $50-60 \%$ in the 1990 s.

${ }^{3}$ Castley (1997) showed Japanese influence on Korea's industrialisation in detail.

${ }^{4}$ Kanaya and Woo (2000) discusses the Japanese banking crisis in the 1990s, in particular the collapse of the asset bubble in the early 1990s.
} 
all East Asian countries. In particular, the similarities between Japan and Korea were significant due to their strong trade networks.

It is fair to say that the Korean industrialisation process followed that of Japan with a time lag of almost a decade. This overlapping transfer of industrial structures from Japan to Korea was explained by the Japanese relocation process, which started in the late 1960s. In Table 2, Korea shows a general pattern of catching up with the Japanese industrial policy a decade after.

Ishii (1997) claimed the reason for the high growth rate in East Asia was its high rate of savings. Even in the 1980s the rate of savings of the household economy in Japan was around $17 \%$, which was twice as much as those in the advanced Western countries. It is true that the high rate of savings in East Asia is one of the common factors for its fast growth. However, the role of banks in the process of allocating the funds into appropriate industries and enterprises should not be overlooked. As Ishii (1997) pointed out for Japan, the main part of the funds for industrialisation in East Asia was not procured directly from the capital market but supplied indirectly through various kinds of banks, and the respective central banks provided these banks with funds if necessary.

Cho (1994) explains that the East Asian Governments were heavily involved in the direction of savings fund to achieve development goals in the real sector. Industrialisation in East Asia has not only meant a transformation of an agrarian economy into an industrial economy, but it also means a more focused industrial development in strategic industries such as heavy industries. Thus, the financial sector has never developed independently of the real sector in East Asia. More importantly, the industrial policy dominated financial sector developments leaving the banking sector subordinate to the real sector.

With the increasing importance of East Asian economy in the global context, Japan and Korea have experienced significant pressure from outside on market liberalisation in the both real and financial sectors. Japan faced the pressure earlier than Korea as the Japanese presence in the global organisation predated that of Korea. Requests for eliminating tariff and non-tariff trade barriers were one of the most common pressures in the real sector, whereas the liberalisation of interest rates and mobility of capital were often required by global institutions such as IMF, World bank and OECD. For instance, the OECD entry condition for Korea included capital market liberalisation. ${ }^{5}$

Therefore, the East Asian Governments started to lose their tight control over industrial policy and banking operation. Large enterprises increased their activities overseas both in production and financing in the wake of globalisation and domestic economies in East Asia were left behind. Cowling and Tomlinson (2000) explain a case of strategic failure about a hollowing out of Japanese industry caused by the relocation of Keiretsus and other multinationals. ${ }^{6}$

When the Japanese bubble burst in 1990 and the banking crisis followed a year after, mergers between banks were recommended. However, the Keiretsus were the main hurdle to both large-scale mergers and massive corporate restructuring as city banks in Japan were at the core of respective Keiretsus. These large business groups, Keiretsus, had cross-shareholdings with the group banks, which has worked in favour of industrial

\footnotetext{
${ }^{5}$ Korea had to comply with the minimum requirements set by 'OECD Codes of Liberalisation of Capital Movements and Current Invisible Operations'

6 'Hollowing out' as a result of outward FDI (foreign direct investment) when the domestic cost base increases.
} 
policy during the fast growing period. However, when the real sector started to deteriorate, the Keiretsu holdings in the city banks proved to be a substantial obstacle. ${ }^{7}$

The Korean case is somewhat different, as there is no large group bank publicly known, tied via cross-shareholdings. However, the strong long-term relationship between certain banks and Chaebols, which are the Korean version of Keiretsus, turned out to be a problem after the recent crisis. Despite the absence of group banks, the loan portfolio of Korean banks was concentrated on a small number of Chaebols. ${ }^{8}$

\section{Background Literature}

There has been much research to explain the causes of Korea's economic growth and many attribute Korea's growth to the strong industrial policy adopted by the Government. In order to finance this industrial policy, the Korean banking system was reorganised. ${ }^{9}$ Cho (1994) explains that the reason the Korean banking system was under tight government control was to aid strategic investments to finance development plans. East Asian Governments promoted a group of strategic industries as listed in Table 2 and regulation was designed to direct the money flow to such target industries. ${ }^{10}$

On the other hand, macroeconomists often discuss the optimal mix of government policies to explain economic growth in a country. In particular, the recent crisis in Asia brought more attention to the role of monetary policy in an economy. ${ }^{11}$ However, the economic success in East Asia may have more to do with the credibility of hands-on development policy in the private sector alongside monetary policy. The liquidity for the development was provided and the fund flows were carefully directed to the strategic industries. The signal of Government's intention was clear and credible to the private sector via announced development plans without any policy inconsistency. ${ }^{12}$

Given the special attributes of banking industry, the theory of financial intermediation indicates measuring the both quantity output and quality of banks is not as straightforward as for non-financial firms. In addition to the intangible nature of banking output, it is difficult to account for quality in banking service. ${ }^{13}$ Heffernan (1996), Klein (1971) and Clark (1988) discussed the relevant concepts of bank output and input. ${ }^{14}$ Despite the importance of commercial banking as a major financial intermediary, there has been little consensus as to what constitutes a workable and productive theory of the banking firm. Klein (1971) claims that neo-classical microeconomic analysis is rarely used to explain bank behaviour, primarily because there is so little agreement concerning even the most fundamental concepts. In the face

\footnotetext{
${ }^{7}$ Tsutsui (1999) explains the obstacles faced by Keiretsus and the group banks in detail.

${ }^{8}$ It appears to be bilateral oligopoly suggested by Waterson (1984) using Galbraith (1954) examples in American Capitalism.

${ }^{9}$ The importance of the banks' role in financing this industrial policy is well documented in 'Financial System in Korea (1998)' published by The Bank of Korea.

${ }^{10}$ Castley (1997) explains the industrialisation process in East Asia as a form of ladder where each rung has to be scaled before moving on to the next. His illustration of the ladder is simplified as 1/ Pre-industry with primary products, 2/ Labour-intensive industries, 3/ Capital-intensive industries, and 4/ Knowledge or technology-intensive industries.

${ }^{11}$ Agenor et al (1999) laid out excellent models for monetary policy and macroeconomic aspects of financial sector in order to explain the recent Asian financial crisis.

${ }^{12}$ Castley (1997) lists suggested causes for East Asian economic success including consistent macroeconomic policies, high rates of investment, command economy through government intervention, total commitment of regime to economic growth.

${ }^{13}$ See Gordon (1990) for hedonic price adjustment.

${ }^{14}$ They define loans and deposits as output and input respectively.
} 
of conceptual difficulties in drawing the analogy between a bank and the typical firm of neo-classical analysis.

Among various competition models in banking, Gehrig (1996) and Matutes and Vives $(1996$; 2000) included monopolistic competition with horizontal and vertical product differentiation, where the equivalent quality parameter is the degree of branching. However, the weakness of the monopolistic competition approach is the lack of empirical evidence, given the imperfect nature of the industry. There are information gaps among borrowers and lenders and imperfect information lies at the centre of banking sector dynamics. Freixas and Rochet (1997) explain that intermediaries in the brokerage market, including banking, can affect their trading probabilities by establishing an information and communication network. As communication possibilities across potential traders are imperfect, Freixas and Rochet (1997) claim that, several firms, not one, will offer similar or identical intermediary services. Gehrig (1996) shows that the structure of financial markets is usually fairly concentrated with a few large firms and monopolistic competition market conditions will not be present.

On the other hand, Klein (1971) assumed that banks maximise profits in the course of the intermediation activity and thus, the microeconomic analysis of banks has been influenced by industrial organisation theory. This led to the development of banking competition models and to empirical studies based on methods developed for industrial economics. Klein (1971) and Monti (1972) considered a bank as a firm maximising its net present value of assets and established a landmark model of banking.

Among other competition models in banking, Repullo (1995) and Chiappori et al. (1995) applied horizontal differentiation to banking. In these models, the main difference between banks and non-financial firms is that banks compete in two markets instead of one, i.e. deposits and loans markets. However, they assume that under perfectly competitive interbank market conditions complete independence of the two activities of the bank can be obtained. The predictions of these models are that banking industries should be fragmented, and market shares should be symmetrically distributed. On the other hand, Gehrig (1996) and Matutes and Vives (1996; 2000), introduce network externalities to explain how asymmetric configurations in market share could arise in banking. This asymmetric information paradigm has emerged as a mainstream approach for recent banking analyses.

The traditional approach to early empirical studies of banking was based on the structure-conduct-performance (SCP) paradigm. ${ }^{15}$ Bain (1951) supposed a one-way linear relationship of causality, which runs from structure (the level of concentration) to conduct (the degree of collusion or competition), and then to performance (profitability). Therefore the structure of an industry is important to the understanding of its performance. However, the application of SCP paradigm has been subject to considerable criticism as it neglected feedback. Cowling (1976) suggests the structureperformance relationship be a recursive system of feedback with substantial lags. Berger (1995) also questioned the results obtained following the SCP paradigm. Despite the criticism, the SCP paradigm provided the foundation for the study of market structure.

In general, the banking industry is highly concentrated. Kolari and Zardkoohi (1987) and Clark (1988) explained the concentration in banking industry with economies of scale and scope. Economies of scale in banking and financial intermediation allow

\footnotetext{
${ }^{15}$ Baltensperger (1972), Gilbert (1984) and Hannan (1991) used the SCP paradigm.
} 
banks to exercise market power or to pre-empt potential rivals' entry. Although banking systems tend to be quite concentrated, in some developed countries, the United States shows a fragmented structure. ${ }^{16}$ However, this fragmentation exists primarily as a result of regulation on inter-state branching designed to deal with their concern about financial power.

Game theory provides another useful approach for analysing banking competition. When banks are to maximise their profits under SCP paradigm, the market structure can be investigated under a two stage game theoretic model. Banks can play two different games, competing in prices or quantities. As an example of price competition, banks enter the market with sunk costs. The exogenous sunk cost such as capital requirement to open a bank is a fixed set-up cost as it is fixed by an entry regulation and only varies in the presence of change in regulation. The endogenous sunk cost of branching is a variable set-up cost, which is considered to be a parameter for an escalation mechanism in vertical product differentiation in banking. ${ }^{17} \mathrm{~A}$ similar application to internet bank networks is feasible.

Chiappori et al. (1995) derived the equilibrium number of banks under various regulatory conditions and suggested the equilibrium number of banks under regulation is larger than that under free market condition but none of them is socially optimal. Cerasi et al. (2002) also looked at the impact of deregulation on concentration and branch networks in European banking. Since deregulation reduces profits for a given branching network, fewer firms find it profitable to enter the industry and therefore the degree of concentration rises. On the other hand when the banks collude, they establish a smaller network compared with competition as opening new branches damages rivals by stealing their clients. By coordination, they will avoid this damage. However, her empirical analysis shows the weakness in explaining the feedback process of structureperformance relation.

\section{Empirical Analyses of the Banking Structure in Japan and Korea}

In a concentrated industry, there exist economies of scale and thus higher profits are expected under a concentrated market structure. The rationale behind this prediction is that in a concentrated industry, firms behave as oligopolists, earning high profits. However, the SCP paradigm is not always justified if the strategic behaviour of firms is taken into account. For instance, there are barriers to entry where banks can act together collusively against new entries. One other point, which is missed out in the SCP paradigm is the feedback that the higher the profits, the greater the number of firms that enter the industry and thus lower the level of concentration. This feedback is exemplified within the regulatory framework. Tougher competition leads to lower profits and thus many firms are driven out of the industry and hence raises concentration.

There have been studies on the impact of deregulation on the structure of the banking industry, but most of them focused on EEC banking industries and there are no studies on East Asian banking. Given the peculiarity of industrial policy and the role of banks in East Asia, it is worth trying to estimate the impact of deregulation on concentration and the structure of banking industry in Japan and Korea. The process of deregulation

\footnotetext{
${ }^{16}$ See Macey (2001) and Calomiris (1997).

${ }^{17}$ Sutton $(1991,1998)$ laid out a model of sunk cost and market structure and discusses extensively on escalation mechanism and the market structure.
} 
since 1979 in Japan and since 1988 in Korea provides the natural framework to assess this impact, especially when the process accelerated following the Asian financial crisis in 1997.

\subsection{The Data}

In order to test the predictions of SCP paradigm with modification for feedback, a set of variables for Structure (concentration), Conduct (branching and pricing) and Performance (profitability) were chosen and the relevant indices computed with respect to the strategic variable, deposits. ${ }^{18}$ The number of branches per bank measured the size of the branch network. Finally, three dummy variables were used to capture the effect of different types of deregulation: 1/ deregulation of deposit interest rates; 2 / deregulation of branching restriction, and 3/deregulation of cross-financial sector entry.

The time-series data in aggregate for both Japan and Korea were constructed using 22 nationwide banks and 64 regional banks in Japan (86 banks) and 18 nationwide banks and 10 regional banks in Korea (28 banks). Hence the panel of all 114 commercial banks in the two countries over the 28 year period from 1976 to 2003 were used in the calculation of the time-series data for the analyses. However, one should note that this data set has only time-series features as panel attributes are lost when calculating the market structure variables in aggregate. When a bank changes its name after restructuring, it was recorded as a new entry in the data set. Changes in the number of commercial banks in Japan and Korea are shown in Table 1 with a substantial number of mergers.

These two countries are chosen for several reasons: 1/ the times series data are not readily available for the entire set of commercial banks in other countries in the region; $2 /$ the available data are more reliable compared to those of other countries' banks; 3/ the banking sector in Japan and Korea have undergone a substantial consolidation; 4/ both countries have implemented progressive deregulation in the banking sector, and finally $5 /$ the industry restructuring in Japan and Korea are often replicated in other newly industrialised countries (NIEs) and the restructuring of the banking sector is no exception.

For both countries, the data for all commercial banks were aggregated into timeseries instead of panel. The Japanese data were collected from the Bank of Japan (BOJ hereafter) and Japanese Bankers Association (Zenginkyo hereafter) publications and the Korean data came from the Bank of Korea (BOK), Financial Supervisory Services (FSS) and Maekyung-Annual Corporation reports.

The classification of deposit institutions set by the respective central banks is used. The econometric model is tested on commercial banks (i.e. nationwide city banks and regional banks), as foreign bank branches and specialised banks do not participate in the majority of competitive activities given the prevailing regulation. Moreover, city and regional banks represent nearly $50 \%$ of the deposit market and they are the ones that compete in the more realistic sense.

\subsection{Description of Variables}

The variables are classified into three groups following the SCP paradigm. The level of concentration, market size and branch concentration were included in Structure as shown in the dependent variable section in Table 5. Deposit and loan rates are taken as a

\footnotetext{
${ }^{18}$ I assume the strategic objective of a bank is to compete for deposits in the market. Hence, I use deposits as the strategic variable.
} 
proxy for price and the average branching as a proxy for quantity. ${ }^{19}$ These price and quantity proxy variables were included in Conduct. Return on deposits was included in Performance. The conduct and performance measures are shown as independent variables in Table 5. Variables included in the 3 groups are discussed in further details hereunder.

There are various ways to measure concentration $\left(\mathrm{CNC}_{\mathrm{t}}\right)$. However, a logit transformation of $C_{5 t}$ (n-firm concentration ratio of top 5 banks in year $t$ ) is used to avoid the problem of an upper limit of $C_{5 t}=1$ and to maintain an identical distribution of residuals at all values of market size. ${ }^{20}$ An n-firm concentration ratio, $\mathrm{C}_{5 \text { t }}$, for top 5 banks is calculated ${ }^{21}$ by aggregating market shares of top five banks in the deposit market for year $t .^{22}$ Sutton (1991) has been using the logit transformation for some time, which was subsequently adopted by others like Cerasi and Daltung (2000). For those who are not familiar with this type of transformation, the conventional Hirschman Herfindal Indices $\left(\mathrm{HHI}_{\mathrm{t}}\right)$ were also used for comparison, although I do not expect to find much difference in results as shown in Figure 3 and 4.

$$
C N C_{t}=\ln \left(\frac{C_{5 t}}{1-C_{5 t}}\right)
$$

The deposit market size $\left(\mathrm{MKS}_{\mathrm{t}}\right)$ was computed in index form in order to deflate for changes in prices and currency devaluation. The total deposit size includes local currency deposits in current, savings and time deposit accounts at city and regional banks, i.e. ordinary banks. ${ }^{23}$

$$
M K S_{t}=\ln \left(\frac{\text { Total Deposit Size }}{t}\right)
$$

The size of the branch network is also calculated in index form for the whole market taking the number of branches per bank.

$$
A V B_{t}=\ln \left(\frac{\text { Total number of branches }}{\text { Number of banks }}\right)
$$

Branch concentration $\left(\mathrm{BCNC}_{\mathrm{t}}\right)$ is computed in index form as well taking a logarithmic ratio of the number of branches operated by top five banks over total number of branches $\left(B C_{5 t}\right){ }^{24}$

\footnotetext{
${ }^{19}$ Banks expand their branch networks to gain market share in both deposits and loans.

${ }^{20}$ Here, the deposit market size follows the same definition as used for the variable $\mathrm{MKS}_{\mathrm{t}}$, i.e. all the local currency deposits in current, savings and time deposit accounts at city and regional banks.

${ }^{21} C_{5 t}=\sum_{i=1}^{5} s_{i t}$ where $s_{i t}=$ market share of bank $i$ in year $t$

${ }^{22}$ For multi-market conglomerate mergers and market shares, see Mueller (1985).

${ }^{23}$ The deposit size data were taken from 'Bank Management Statistics' published by FSS for Korea and

'Analysis of Financial Statement of All Banks' published by Zenginkyo for Japan.

${ }^{24} B C_{5 t}=\sum_{i=1}^{5} b_{i t}$ where $b_{i t}=\frac{\text { No. of branches operated by bank } i \text { in year } t}{\text { Total No. of bank branches in the market in year } t}$
} 


$$
B C N C_{t}=\ln \left(\frac{B C_{5 t}}{1-B C_{5 t}}\right)
$$

Interest rates on deposits $\left(\operatorname{IRD}_{t}\right)^{25}$ and loans $\left(\mathrm{IRL}_{\mathrm{t}}\right)^{26}$ were directly taken without transformation as $\mathrm{IRD}_{\mathrm{t}}$ and $\mathrm{IRL}_{\mathrm{t}}$ are already normalised with respect to the size of deposits by taking the weighted average of market interest rates. ${ }^{27}$ For the performance measure, Return on deposits $\left(\mathrm{ROD}_{\mathrm{t}}\right)$ was computed as a ratio of net profits over total deposits. ${ }^{28}$ It is important to note that the performance measure cannot be simply the interest margin. Return on deposits $\left(\mathrm{ROD}_{\mathrm{t}}\right)$ is a measure of banks' soundness as nonaccrual interests and provisions for non-performing loans were taken into account. Therefore, return on deposits $\left(\mathrm{ROD}_{\mathrm{t}}\right)$ should definitely be distinguished from interest margins.

In addition to 3 groups of variables, 3 deregulation dummy variables used in the analysis: $\mathrm{D}_{1 \mathrm{t}}$ for deregulation on deposit interest rates, $\mathrm{D}_{2 \mathrm{t}}$ for deregulation of branching restriction, and $\mathrm{D}_{3 \mathrm{t}}$ for deregulation on cross-financial sector entry. Banking licenses in East Asia were initially given out for banking operations only exclusively. However, the deregulation of cross-financial sector entry allowed banks to enter other financial business areas such as securities trading and insurance sales.

These dummy variables take a progressive form based on the gradual deregulation processes, between 0 and 1, with 0 being complete regulation versus 1 being complete deregulation. As deregulation on interest rates in Japan and Korea was carried out in a progressive way as shown in Table 3 and 4, the relative magnitude of deregulation impact was determined according to local authorities statements, which imply the first stage of deregulation has more weight than the rest. For instance, $D_{1 t}=1$ means complete deregulation on interest rates in 1995 for Korea, whereas $D_{1 t}=0.5$ represents deregulation is only half way through the process as described in Table 5. Figure 13 illustrates the progressive deregulation on deposit interest rates whilst Figures 14 shows a one-off deregulation of branch restriction in Japan in contrast to the full restriction on branching in Korea. For the deregulation of cross-financial sector entry, Figure 15 illustrates a one off deregulation in Korea and a two-stage deregulation in Japan.

Finally, in order to investigate the impact of size distribution of market concentration and compare the results from nationwide banking with those from regional banking, the Hirschman Herfindal Indices $\left(\mathrm{HHI}_{\mathrm{t}}\right)$ were calculated and scaled by 100 for: ${ }^{29} 1 / \mathrm{all}$

\footnotetext{
${ }^{25}$ For Korea, indicative interest rate on time deposits for more than 1 year and less than 2 years (but effective for 1 year or more before Dec. 5, 1988) published by BOK is used, where the rate is an average weighted by amount from 1996. For Japan, the rate is an average weighted by amount for total deposits published by Zenginkyo.

${ }^{26}$ For Korea, indicative interest rate on loans of general funds up to 1 year for general enterprises at the end of period, where the rate is an average weighted by loan of banking funds from 1996. For Japan, the rate is an average weighted by amount for total loans published by Zenginkyo.

${ }^{27} \mathrm{IRD}_{\mathrm{t}}$ and $\mathrm{IRL}_{\mathrm{t}}$ are taken from 'Money and Banking' published by BOK for Korea (http://ecos.bok.or.kr/) and 'Analysis of Financial Statement of All Banks' published by Zenginkyo for Japan.

${ }^{28}$ No logarithmic transformation is taken, as the distribution of residuals is normal with the simple ratio form.
} 
commercial banks $\left(\mathrm{HHI}_{\mathrm{t}}\right)$; 2/ nationwide banks $\left(\mathrm{HHIN}_{\mathrm{t}}\right)$, and 3/ regional banks $\left(\mathrm{HHIR}_{\mathrm{t}}\right)$. One could argue that the $\mathrm{HHI}_{\mathrm{t}}$ is more effective measures for market concentration as it intrinsically gives weight to both number of firms in the market and their market share distribution.

\subsection{The Econometric Model}

An econometric model is tested in a SCP paradigm framework using two-stage least squares (TSLS) of a system of simultaneous equations:

$$
\begin{aligned}
C N C_{t}=\alpha_{0}+\alpha_{1} M K S_{t}+\alpha_{2} I R D_{t-1} & +\alpha_{3} I R L_{t-1}+\alpha_{4} A V B_{t} \\
& +\alpha_{5} R O D_{t-1}+\alpha_{6} C N C_{t-1}+\sum_{k=1}^{3} \delta_{k t} D_{k t}+\varepsilon_{1 t} \\
B C N C_{t}=\beta_{0}+\beta_{1} M K S_{t}+\beta_{2} I R D_{t-1} & +\beta_{3} I R L_{t-1}+\beta_{4} A V B_{t} \\
& +\beta_{5} R O D_{t-1}+\beta_{6} B C N C_{t-1}+\sum_{k=1}^{3} \varphi_{k t} D_{k t}+\varepsilon_{2 t} \\
A V B_{t}=\gamma_{0}+\gamma_{1} M K S_{t}+\gamma_{2} B C N C_{t} & +\gamma_{3} R O D_{t-1}+\gamma_{4} A V B_{t-2}+\sum_{k=1}^{3} \lambda_{k t} D_{k t}+\varepsilon_{3 t}
\end{aligned}
$$

, where $\mathrm{k}=1,2,3$ for three deregulation dummy variables. ${ }^{30}$

Equations 5 and 6 use one of the most general forms of specification. They are designed to detect the effects of deposit market size $\left(\mathrm{MKS}_{\mathrm{t}}\right)$, lagged interest rates on deposits and loans $\left(\operatorname{IRD}_{\mathrm{t}-1}\right.$ and $\left.\operatorname{IRL}_{\mathrm{t}-1}\right)$, average branch network size $\left(\mathrm{AVB}_{\mathrm{t}}\right)$, lagged return on deposit $\left(\mathrm{ROD}_{\mathrm{t}-1}\right)$, lagged concentration $\left(\mathrm{CNC}_{\mathrm{t}-1}\right.$ in eqn. $5 ; \mathrm{BCNC}_{\mathrm{t}-1}$ in eqn. 6$)$, and three types of deregulation $\left(\mathrm{D}_{1 \mathrm{t}}, \mathrm{D}_{2 t}\right.$, and $\left.\mathrm{D}_{3 \mathrm{t}}\right)$ on the banking concentration $\left(\mathrm{CNC}_{t}\right.$ in eqn. $5 ; \mathrm{BCNC}_{\mathrm{t}}$ in eqn. 6).

On the other hand, Equation 7 takes a form that is simplified by dropping lagged interest rate variables as banks do not consider the level of market interest rates as strategic reasons to expand their branch network size. Equation 7 explains the effects of deposit market size $\left(\mathrm{MKS}_{\mathrm{t}}\right)$, branch concentration $\left(\mathrm{BCNC}_{\mathrm{t}}\right)$, lagged return on deposit $\left(\mathrm{ROD}_{\mathrm{t}-1}\right)$, lagged average branch network size $\left(\mathrm{AVB}_{\mathrm{t}-1}\right)$, and three types of deregulation $\left(D_{1 t}, D_{2 t}\right.$, and $\left.D_{3 t}\right)$ on average branch network size $\left(A V B_{t}\right)$. One should note that I use two-stage least squares (TSLS) given the endogeneity between $\mathrm{AVB}_{\mathrm{t}}, \mathrm{CNC}_{\mathrm{t}}$, and $\mathrm{BCNC}_{\mathrm{t}}$.

This is a dynamic model, which corrects the weakness of the traditional SCP paradigm assumption of a one-way flow of causality. ${ }^{31}$ In order to incorporate a

${ }^{29}$ All three $\operatorname{HHI}_{\mathrm{t}}, \mathrm{HHIN}_{\mathrm{t}}$, and $\mathrm{HHIR}_{\mathrm{t}}$ are obtained by e.g. $H H I_{t}=\frac{\sum_{i=1}^{n} s_{i t}{ }^{2}}{100}$

${ }^{30}$ All three equations are identified as they pass both order and rank conditions. Deregulation on branching restriction $\left(\mathrm{D}_{2 \mathrm{t}}\right)$ is excluded for Korea, as the restriction has not yet been relaxed in Korea.

${ }^{31}$ Cowling (1976), Strickland \& Weiss (1976) and Sutton (1991) pointed out this weakness of SCP paradigm and suggested various alternative methods. Cowling suggested a recursive model and 
feedback feature, interest rates on deposits and loans were taken in lagged forms of one year $\left(\operatorname{IRD}_{\mathrm{t}-1}\right.$ and IRL $\left.\mathrm{I}_{\mathrm{t}-1}\right)$. Effective business plans of most East Asian banks are made on an annual basis reflecting the performance of the previous year. Hence, return on deposit $\left(\mathrm{ROD}_{\mathrm{t}}\right)$ also takes a lagged form $\left(\mathrm{ROD}_{\mathrm{t}-1}\right)$ together with the overall feedback via the lagged dependent variables $\left(\mathrm{CNC}_{\mathrm{t}-1}\right.$ in eqn. 5 ; $\mathrm{BCNC}_{\mathrm{t}-1}$ in eqn. 6). These one-year lagged variables are verified by interviews with banks such as Korea Housing Bank (KHB), Korea First Bank (KFB), and Kookmin Bank (KB) as well as FSS in Korea and Zenginkyo in Japan. ${ }^{32}$ All lagged dependent variables were taken to be with one-year lag except for the average branch network size $\left(\mathrm{AVB}_{\mathrm{t}}\right)$ where two-year lags are used given the nature of data. ${ }^{33}$

Market size $\left(\mathrm{MKS}_{\mathrm{t}}\right)$ was also assumed exogenous in the model as deposit size is not endogenously determined in relation to the market structure measured in concentration. Deregulation dummy variables were considered to be exogenous since the reason for deregulation in East Asia lies in the outside pressure from the international organisations such as G7, OECD, IMF and World Bank.

Concentration $\left(\mathrm{CNC}_{\mathrm{t}}\right)$, branch concentration $\left(\mathrm{BCNC}_{\mathrm{t}}\right)$ and average branch network $\left(\mathrm{AVB}_{\mathrm{t}}\right)$ are the variables determined endogenously as well as contemporaneously based on the number of banks, the number of branches and the concentrations in the market.

So far the examination has focused on whether the relationships between the variables in the model are contemporaneous or have lagged features in constructing the simultaneous equations and have shown exogeneity and endogeneity. This model enables the testing of a variety of propositions,

Structure (Concentration: $\mathrm{CNC}_{t}$, Branch Concentration: $B C N C_{t}$ )

1. the degree of concentration decreases as the market size increases with given set-up costs ${ }^{34}$

2. the degree of concentration in the industry is positively related to the degree of concentration in branching

3. the average branch network size is positively related to the degree of concentration

Conduct (Deposit and loan rates: IRD $D_{t-1}$ and IRL $L_{t-1}$, Branch network: $A V B_{t}$ )

1. the interest rate on deposits is negatively related to the degree of concentration

2. the interest rate on loans is positively related to the degree of concentration

3. the average branch network size is positively related to the degree of concentration

Performance (Return on deposits: $R O D_{t-1}$ )

1. the return on deposits is negatively related to the degree of concentration

Strickland and Weiss suggested a system of simultaneous equations while Sutton claims there is no single specification explains all industries.

${ }^{32}$ The interview with Zenginkyo took place during the visit to its office in Tokyo between 18-20 Dec. 2000 and the interviews with KHB, KFB, KB, and FSS took place in Seoul between 26-30 Dec. 2000.

${ }^{33}$ The Phillips-Perron test of unit roots were conducted for all the dependent variables on their lags and the number of lags were determined accordingly: one-year lag for $\mathrm{CNC}_{\mathrm{t}}$ and $\mathrm{BCNC}_{\mathrm{t}}$ and two-year lag for $\mathrm{AVB}_{\mathrm{t}}$.

${ }^{34}$ Traditionally, the SCP paradigm with feedback predicts higher profit levels as the market size grows and therefore it attracts more entrants and a fragmented market structure is established as a result. 
Deregulation (Different types of deregulation: $D_{1 t}, D_{2 t}$, and $D_{3 t}$ )

1. relaxed regulation leads to a higher degree of concentration

2. deregulation leads to higher degree of concentration in branching

3. deregulation leads to banks with larger branch networks

Traditional literature suggested that the degree of concentration would be negatively related to the size of the market to sunk costs ratio, assuming that the sunk costs are similar across the market. For example, Sutton (1991) explains, for a wide class of homogeneous goods models, including the Cournot and joint profit maximisation models, the industry converges to a fragmented structure, as the ratio of the size of the market to sunk costs becomes large. The larger the market size is, the more room there is for new entries, which leads the market to a more fragmented structure. Cerasi et al. (2002) showed some evidence of a negative relationship between concentration and market size in the banking industries in Europe. Set-up costs for the first branch are mainly due to entry regulation, i.e. the requirement a bank has to meet in order to become operative and the access costs to funds, given by the interbank market. In a single country case like in Japan or Korea, this assumption simplifies the empirical test allowing one to ignore the problem of finding a proxy for set-up costs.

The results from estimating the 3-equation system are reported in Table 6. For the first proposition in Structure, the relationship between the degree of concentration $\left(\mathrm{CNC}_{\mathrm{t}}\right)$ and the market size $\left(\mathrm{MKS}_{\mathrm{t}}\right)$ is positive in Japan but negative in Korea. The coefficient of the market size is statistically significant in Japan but not significant in Korea. These contradicting results between two countries may indicate that the market structure does not entirely depend upon the market size. One could alternatively explain the reason for the contrasting results as the difference in their stage of banking evolution. Assuming endogenous sunk costs as Sutton (1991) suggested, Japan may be a step ahead of Korea in the escalation of concentration as market size increases (see Figure 3 and 4). The deregulation measures, which changed the competition environment in East Asia may explain this contradicting result. Alternatively, the banking sector does not conform to standard results of other industries.

The result for the second proposition in Structure is interesting since the sign on the estimated coefficient of market size $\left(\mathrm{MKS}_{\mathrm{t}}\right)$ in branch concentration $\left(\mathrm{BCNC}_{\mathrm{t}}\right)$ is positive in both Japan and Korea (the coefficients are 0.34 and 0.35 respectively) although neither is significant. The usual prediction is that when the market size increases, the branching network is also increases but the dominant banks expand their branch network even more to pre-empt new entries. Therefore the results are typical evidence for this type of pre-emptive and/or competitive branching activity.

Concerning size of average branch network, the data does not support the third proposition in Structure. The negative relationship between the average branch network size $\left(\mathrm{AVB}_{\mathrm{t}}\right)$ and the market size $\left(\mathrm{MKS}_{\mathrm{t}}\right)$ in Japan can be explained by the dominance of Keiretsu networks (the coefficient of -0.05 significant at $10 \%$ level) which does not need much branching to attract large size banking business as it is mostly secured with the Keiretsu. On the other hand there is a positive relationship between the average branch network size $\left(A V B_{t}\right)$ and the market size $\left(M_{K}\right)$ in Korea, although it is not significant (the coefficient is 0.03). This difference in the results suggests that the banking network between Keiretsus and Japanese banks is more effective than that between Chaebols and Korean banks. This is an important observation as it firstly 
indicates that the banking structure should not be looked at independent of the real sector. Secondly, it also helps us to understand why two countries show divergence in banking restructuring or if not divergence, in different stages of banking evolution.

For the first proposition in Conduct regarding the deposit interest rate $\left(\operatorname{IRD}_{\mathrm{t}-1}\right)$, the results from Japan are consistent although it was significant only in explaining branch concentration $\left(\mathrm{BCNC}_{\mathrm{t}}\right)$. The initial proposition predicted a more fragmented market structure with new entries would raise deposit rates under competition and squeeze interest margins for a given level of loan rate. The results do support this proposition and indicates that dominant banks can afford to pay relatively lower deposit rates in a concentrated market structure.

However, one could probably argue that the banking conduct in the region is not entirely up to the market concentration and the loose competition environment in East Asia where industrial policies and regulation dominated the banking. It is worth noting that banks' entry decision in East Asia has been less sensitive to the banking outlook given the industrial policy as shown in Table 2 but to banking regulation as listed in Table 3 and 4. Therefore, this result should not be looked at independently of changes in regulation, which aim for free competition. On the other hand, the results on deposit rate in Korea are not significant for market concentration $\left(\mathrm{CNC}_{t}\right)$ nor for branch concentration $\left(\mathrm{BCNC}_{\mathrm{t}}\right)$.

The second proposition in Conduct deals with loan rates (IRL $\mathrm{L}_{\mathrm{t}-1}$ ). Following the same logic as in the previous proposition, a positive relationship is predicted between the interest rate on loans ( $\left.\mathrm{IRL}_{\mathrm{t}-1}\right)$ and the degree of concentration $\left(\mathrm{CNC}_{\mathrm{t}}\right)$ for a given level of deposit rate as dominant banks can charge higher loan rates. The results for both Japan and Korean agree with the proposition and the positive relationship is significant at $5 \%$ level in explaining branch concentration $\left(\mathrm{BCNC}_{\mathrm{t}}\right)$.

Once again, as free entry condition has not been common in Korea due to prevailing regulation and the determination of loan rates and deposit rates were predominantly regulated by the Korean Government in favour of its industrial policy, changes in interest margins do not necessarily seem to affect new entries and hence the market structure. Hence, it does not seem appropriate to consider interest rates on loans and deposits as only strategic variables in banking competition without taking regulation and NPL provisions into consideration.

It is clear that increasing margins allowed more market power to the incumbent banks in Japan to pre-empt new entries via branching. On the other hand, the proposition holds in the Korean case without much significance, which suggests that it may need other explanatory variables over and above interest rates on loans and deposits.

Regarding the relationship between the average branch network size $\left(\mathrm{AVB}_{\mathrm{t}}\right)$ and the concentration $\left(\mathrm{CNC}_{\mathrm{t}}\right)$, the initial proposition of a positive relationship holds only for the Korean case explaining market concentration $\left(\mathrm{CNC}_{t}\right)$. The coefficients are negative in all other cases. This third proposition in Conduct is rooted in the idea that increasing network size in order to provide services to a bigger market may create a concentrated market structure. However, the results in both Japan and Korea show more or less evidence of negative relationship (except for the market concentration in Korea). This may indicate a banking inefficiency in East Asia where branch network expansion does not increase market share.

Finally, the last proposition reveals a relationship between Performance and market structure. The Japanese data show no evidence of relationship between the 
concentration $\left(\mathrm{CNC}_{\mathrm{t}}\right)$ and the return on deposit $\left(\mathrm{ROD}_{\mathrm{t}-1}\right)$, whereas the Korean data did show a negative relationship between branch concentration $\left(\mathrm{BCNC}_{\mathrm{t}}\right)$ and return on deposit $\left(\mathrm{ROD}_{\mathrm{t}-1}\right)$, which is significant at $10 \%$ level. The result suggests that banks tend to leave the market or merge together to restore some power in light of falling profitability. More importantly, this reassures the proposition drawn from the simple theoretical model with NPLs, that indicates the larger the NPLs, i.e. less profitable or lower return on deposit, more concentrated the market is. However, there is a problem interpreting the case of high profitability attracting new entries, as a free entry condition has not been applicable in Japan and Korea given the strict regulation on licensing new banks and new branches as indicated in Table 3 and 4.

It is worth noting that interest margins and return on deposits are two different concepts as the latter does include the risk effects of loans offered by the banks whereas the former does not factor in the risk returns but simply represents the interest rate strategy, i.e. pricing strategy. This is clear in the figures 9 to 12. Figure 9 illustrates the historic movement of interest rates on deposits and loans in Japan which translates into interest margins (solid line) in Figure 10 whilst the dashed line in the figure represents return on deposits. Similarly, Figure 11 shows the historic movement of interest rates on deposits and loans in Korea whilst Figure 12 compares the Korean interest margins to its return on deposits. In Japan it seems difficult to conclude any relationship between interest margins and return on deposits in Japan. On the other hand, there is evidence of stability in return on deposits in Korea (except for the 1997 financial crisis period) despite the fluctuation in the interest margins.

Concerning the deregulation, it is necessary to specify which type of deregulation among the three $\left(D_{1 t}, D_{2 t}\right.$ and $\left.D_{3 t}\right)$ is considered in each case. The first proposition relies on deposit rate deregulation $\left(\mathrm{D}_{1 \mathrm{t}}\right)$, which is one of the most crucial types of deregulation in the SCP framework as it indicates a shift from price-cap regulation to rate-of-return regulation. With the deregulation on deposit rate $\left(\mathrm{D}_{1 \mathrm{t}}\right)$, banks are expected to compete more vigorously and thus created more concentrated market structure to obtain some market power. Similarly, branch concentration $\left(\mathrm{BCNC}_{\mathrm{t}}\right)$ was expected to increase with deregulation in the process of mergers and exits. However, the results do not give any clear sign of direction in the relationship except for the case where movements in average branch network size $\left(\mathrm{AVB}_{\mathrm{t}}\right)$ in Japan were explained. All three deregulation measures here show significant evidence for smaller branch network size. This seems to explain adjustments in banking activity from unnecessary branch expansion under regulation to more rationale and efficient branch expansion. This type of irrational branch expansion was not unknown when banks have to take advantage of granted branching licenses under strict control over branch licensing.

Both the Japanese and the Korean data showed a negative relationship between deregulation on deposit rate $\left(\mathrm{D}_{1 \mathrm{t}}\right)$ and the concentration $\left(\mathrm{CNC}_{\mathrm{t}}\right)$ although they are not significant. The negative relationship could be related to the inflexible deposit rates around zero in Japan and the moderate regulation in Korea. Thus, the deposit rate deregulation $\left(\mathrm{D}_{1 \mathrm{t}}\right)$ leaves little room for East Asian banks to strategically move rates and thus affect the market structure. The feedback process of SCP paradigm going through the deposit rates in East Asia is somewhat disconnected for the above reason.

The relationship between the deposit rate deregulation $\left(\mathrm{D}_{1 \mathrm{t}}\right)$ and the branch concentration $\left(\mathrm{BCNC}_{\mathrm{t}}\right)$ was found to be positive in Japan whereas the Korean data show the opposite direction although the coefficients are not significant. The Korean case 
should be re-examined in the future since the negative relationship could be only temporary given the short history of deregulation.

It is interesting to notice that the relationship between the cross-sector entry deregulation $\left(\mathrm{D}_{3 \mathrm{t}}\right)$ and the concentration $\left(\mathrm{CNC}_{\mathrm{t}}\right)$ in both Japan and Korea is positive, although not significant. One explanation can be that the cross-sector synergy effects lead banks to merge across the financial sector. The other explanation can be that the incumbent banks merge to act against the new entrants from neighbouring financial industries. The latter is an interesting result as it explains banks' entry deterrent activities when they face potential new entrants due to deregulation.

The relationship between the cross-sector entry deregulation $\left(\mathrm{D}_{3 \mathrm{t}}\right)$ and the average branch network size $\left(\mathrm{AVB}_{\mathrm{t}}\right)$ was positive in Korea. The rationale behind this is similar to the second proposition concerning the Korean banks' entry deterrent activities. Banks seem to expand their size of branch network to deter new entrants.

However, the Japanese data indicated a negative relationship between the crosssector entry deregulation $\left(\mathrm{D}_{3 \mathrm{t}}\right)$ and the average branch network size $\left(\mathrm{AVB}_{\mathrm{t}}\right)$, which was also significant. These opposite results can be looked at in parallel with the phases of financial sector development. Korea as an example of a less developed banking industry enhances pre-emptive behaviour against potential new entries from other financial industries. On the other hand, as the Japanese banking industry is relatively more mature, a lifting of cross-sector entry restriction can create synergy effects among various financial firms rather without expanding their branch network size.

The average branch network size $\left(\mathrm{AVB}_{\mathrm{t}}\right)$ in Japan show several significant results for some variables. First, the market size $\left(\mathrm{MKS}_{\mathrm{t}}\right)$ is negatively associated with the branch network size $\left(\mathrm{AVB}_{\mathrm{t}}\right)$ and the coefficient of -0.05 is significant at $10 \%$ level. This indicates that as market size increases, the banks tend to downsize their branching network in Japan (see Figure 8). On the other hand, branch concentration $\left(\mathrm{BCNC}_{\mathrm{t}}\right)$ is positively related to the average branch network size $\left(A V B_{t}\right)$ in Japan suggesting that dominant banks' branch network expansion increases the overall average branch network size. However, the results for the Korean average branch network size are showing the opposite signs. One could argue this is because Korean banks have not yet started downsizing branch network as shown in Figure 8.

It is also important to note that the impacts of all three deregulation dummy variables $\left(D_{1 t}, D_{2 t}\right.$, and $\left.D_{3 t}\right)$ on the average branch network size $\left(A V B_{t}\right)$ in Japan are significantly negative which means that the Japanese banks' reaction towards banking liberalisation is to cut down their branch network size to reduce their costs and improve efficiency.

The lagged dependent variables are all positive and significant at $1 \%$ level as expected indicating the substantial path dependence in banking structure.

From a quick overview of Figure 5 and 6, it is noticeable that the Japanese banking has undergone a major consolidation in nationwide banking throughout the last 3 decades with acceleration whilst the regional banks pursued a more fragmented market structure since 1990s. This is not so obvious in Figure 1. By contrast, the number of Japanese banks declined substantially in the nationwide banking whereas the regional banking actually had a new entrant during the sample period.

On the other hand, the Korean banks have experienced a similar concentration path in both the nationwide and the regional banking heading towards a more fragmented market structure until the early-mid 1990s and a more concentrated market structure since the late 1990s. One interesting observation to make here is that the banking 
consolidation is achieved across both nationwide and regional banking in Korea whilst the Japanese banking consolidation is solely due to the nationwide banking.

The results of the Hirschman Herfindal Index measures presented in Table 7 also suggest that there are differences in the market structure and the banking behaviour in the SCP paradigm between nationwide banks and regional banks.

One noticeable difference between the results from the concentration index estimation in Table 6 and the Hirschman Herfindal Index (HHI) estimations in Table 7 is that the market size variables $\left(\mathrm{MKS}_{\mathrm{t}}\right)$ are more noticeably significant and all positive in Table 7 which uses HHI. This positive relationship between concentration and market size variables clearly supports Sutton's (1991) argument of escalation in concentration with endogenous sunk costs, which are associated with the expansion of branch network in banking.

It is noticeable from Table 1 that Korea is in a different pace and stage of banking evolution, which indicates a large number of new entries as well as M\&As in Korea in contrast to no new entry in Japan during the sample period. A similar conclusion can be drawn from Figure 4 where Korean banking concentration moves from a highly concentrated market $(\mathrm{HHI}>18)$ to an unconcentrated market $(\mathrm{HHI}<10)$ and is moving back up to a moderately concentrated market $(10<\mathrm{HHI}<18)$. By contrast, the Japanese banking remains unconcentrated (HHI $<10)$ even after the significant consolidation in the nationwide banking. ${ }^{35}$ This is mainly due to the fragmented regional banking in Japan.

Therefore it is crucial to note that the two countries adopted different strategies for their regional banks whereby Japan took more fragmented banking structure for its regional banks whilst Korea took a same policy of consolidation for both nationwide and regional banks as presented in Table 1, Figure 5 and 6. Perhaps the overall market size covered by regional banks differ since Japanese regional banks tend to be larger compared to Korean regional banks and they tend to have more geographical monopoly as Japan is formed as a group of islands. On the other hand, Korean regional banks operate in a relatively smaller scale and are less geographically differentiated from one another.

Another interesting result is that the Japanese nationwide banks show a significantly negative relationship between market concentration $\left(\mathrm{HHIN}_{\mathrm{t}}\right)$ and deposit interest rates $\left(\operatorname{IRD}_{\mathrm{t}-1}\right)$, whilst regional banks show positive relationship for the same pair $\left(\mathrm{HHIR}_{\mathrm{t}}\right.$ and $\left.\mathrm{IRD}_{\mathrm{t}-1}\right)$.

On the other hand, the signs are reversed for the loan rates (IRL $\left.L_{t-1}\right)$ whereby higher loan rates suggests more concentrated nationwide banking whilst lower loan rates are associated with more concentrated regional-banking in Japan, which is significant at 5\% level. In other words, dominant Japanese nationwide banks seem to be able to stretch their interest margins under a more concentrated market structure as opposed to those in the regional banks cannot. Perhaps one explanation for the reversed sign for the Japanese regional banks is that they operate more or less as a regional monopoly and therefore even under fragmented market their interest margins can be stretched further within their respective geographical markets.

\footnotetext{
${ }^{35}$ The European Commission and the US Department of Justice classify market conditions according to HHI (unscaled): 1/ less than 1000 (i.e. 10 in scaled HHI in this paper) as unconcentrated; 2/ between 1000 and 1800 as moderately concentrated, and 3/ over 1800 as highly concentrated.
} 
On the Korean banking side, the results look more significant in the regional banking, especially the return on deposit $\left(\mathrm{ROD}_{\mathrm{t}}\right)$ effects are well captured and supports the proposition on performance whereby lower returns i.e. larger non-performing loans are associated with a more concentrated market structure.

\section{Comparison between Japan and Korea}

Although many economists showed similarities between Japan and Korea during the industrialisation period after World War II, very few people tried to explain differences between the two countries. This empirical analysis on the banking sector adds some value in this context. Despite the close interdependency with respect to trade and industrial structure, the banking sector has shown evidence that they were taking fundamentally different steps towards restructuring, although the overall path of restructuring looks similar at first sight.

Japan seemed to have taken a prolonged plan for restructuring compared to Korea where banking deregulation and restructuring has only just begun. Table 3 on Japanese banking liberalisation dates back to 1978 whereas Table 4 indicates the Korean banking liberalisation has only begun since 1991. One important point to make regarding interest rates is the Japanese banks cannot truly compete in interest rates as they are more or less bounded around zero currently. By contrast, Korea seemed to have moved faster towards restructuring within a short period. In this context, one could argue the divergence in their restructuring mainly due to the pace of restructuring and/or the respective stages in the restructuring time horizon where two countries stand. In Figure 7 , branch concentration $\left(\mathrm{BCNC}_{\mathrm{t}}\right)$ in both countries follows a similar path of a $\mathrm{U}$ shape, i.e. a move towards branch fragmentation until late 1980s in Japan and until later 1990s in Korea followed by a series of consolidation. However, the Japanese banking seems to have taken a longer time horizon whilst Korean banking took a drastic adjustment over a short period.

On the other hand, average branch network size has taken a rather similar path until early 1990s and then diverged as the Japanese banking started downsizing their network size alongside the ongoing M\&As (see Figure 8). It is an important point to make that the Korean banking has not downsized its branch network size although its general move towards concentration are revealed on the surface. This suggests that the drastic consolidation in Korea did not seem to have really triggered banking efficiency.

\section{Conclusions}

The role of East Asian banking in industrialisation was carefully discussed. To help understand the East Asian banking structure, the determinants of the industry concentration were analysed. Concentration depends on the market size for given set up costs as well as banks' conduct and their performance. This recursive process is affected by regulation to some degree. Some of the predictions suggested by the simple theoretical model are also tested on a time-series sample of Japanese and Korean commercial banking industry.

In East Asia, the banking concentration rises when deposit market size increases as a consequence of deregulation process in banking industry. Although there is no convincing pattern of events in East Asia supporting the prediction of the deregulation on interest rates, other types of deregulation such as relaxing branching restrictions and cross-financial sector entry restrictions have shown positive relationship with the banking concentration with an increasing pattern of concentration in the time path. This 
reaffirms that banking industry structure does not conform to standard convergence theory in concentration with a given sunk cost. The evolution of banking concentration has been non-monotonic in East Asia.

The econometric model predicts average branch network size to increase as market size increases, whereas deregulation leads to an expansion of the average size of branch network. The data support that deregulation increases the average size of branch network. However, there is no convincing evidence of a positive relation between average branch network size and degree of concentration in the industry in the presence of deregulation.

The relationship between the loan rates and the concentration was significantly positive in Korea. However, a more important result is that Japan and Korea are not going through an identical path in terms of banking restructuring. This overturns most academic claims about similarities between Korea and Japan in their economic development. They might just have started a diverging path in financial sector development. This divergence path needs further studies.

The impact of deregulation is measured in terms of deregulation on deposit rates, branching restriction, and cross-sector entry restriction. The data show that deregulation of deposit rates has a direct impact on concentration and branch concentration. It is also important to note that the Korean banks are using unambiguous entry deterrent tactics when they face new entrants following the deregulation on cross-sector entry within the financial industry.

There are several limitations in this analysis. First of all, some of the conclusions are based on weak evidence due to the limited number of observations available. Another limitation is that the restructuring process has short history and long-term effects have to be further studied. However, this research exercise is still useful in discussing the short-term impact of deregulation on the structure of banking system. The other limitation is that there are differences in entry costs and therefore, the impact of entry costs on the banking structure can vary, when Japan and Korea are compared. I tried to explain the banking sector and the real sector coherently by linking the industrial policy development with the evolution of banking sector in East Asia. However, there is scope for future research regarding this link between the real sector and the financial sector.

In this paper, I have investigated what has already happened with respect to the structure of banking in East Asia in relation to concentration and deregulation. Many of the propositions were supported by the test results both theoretically and empirically. I do, however, believe it is worth having a closer look at the on-going process of deregulation in order to predict the future banking structure in East Asia. For instance, alongside the mergers between domestic commercial banks, M\&A activity by foreign banks has just started to become politically socially acceptable in rescuing distressed Korean commercial banks. On the other hand, Japan is expecting a significant consolidation not only among commercial banks but also across all the financial institutions. The impact of different types of consolidation will definitely be an interesting area for future investigation. 


\section{Appendix}

Table 1. Changes in the Number of Commercial Banks

$\begin{array}{llll}\text { Dec-76 } & M \& A & R & T\end{array}$

A Peak Dec-03

\section{Japanese Banks}

$($ Total No. $=86)$

Nationwide (22)

Regional (64)

13

63

$-5$

-5

$-1$

-1
0

0

Dec-85

Korean Banks

$($ Total No. $=28)$

Nationwide (18)

Regional (10)

5

$-9$

促

$\begin{array}{lll}0 & 13 & 7 \\ +1 & 64 & 64\end{array}$

Dec-97

Source: Japanese Banks - Principal Financial Institutions by Zenginkyo, and Korean Bank Management Statistics by Financial Supervisory Service (FSS).

\section{N.B.:}

1) M\&A: mergers and acquisition; R: revocations; T: transformations; A: authorisation of new entities.

2) In case of $M \& A s$ and a subsequent change of bank name for a newly merged one, it has been counted as only one M\&A instead of counting as two M\&As and an authorisation of a new entity.

3) When a bank changed its name, the data set recorded as a new bank although it is not counted as an authorisation of new entity in the above table.

Table 2. Evolution of Industrial Policies in Japan and Korea

\begin{tabular}{|l|l|l|}
\hline Approximate period & Japan & Korea \\
\hline $1990 \mathrm{~s}$ & High-tech and service industries & Knowledge-intensive industries \\
\hline $1980 \mathrm{~s}$ & $\begin{array}{l}\text { Knowledge-intensive (or high-tech) } \\
\text { industries }\end{array}$ & Heavy industries \\
\hline $1970 \mathrm{~s}$ & $\begin{array}{l}\text { Knowledge industries and heavy } \\
\text { industries }\end{array}$ & $\begin{array}{l}\text { Heavy industries (steel, chemicals, } \\
\text { ships, electronics) }\end{array}$ \\
\hline $1960 \mathrm{~s}$ & Heavy industries(steel and ships) & Light industries (textiles) \\
\hline $1950 \mathrm{~s}$ & Light industries (textiles) & Primary products (food products) \\
\hline
\end{tabular}

Source: Castley (1997), Korea's Economic Miracle 
Table 3. Japanese Banking Liberalisation: post-1978

\begin{tabular}{|c|c|}
\hline Liberalisation measure & Date effective \\
\hline Short-term interest rates liberalised & 1978 \\
\hline Issuance of CD started & May 1979 \\
\hline FX control eased by amending the Law & Dec 1980 \\
\hline Regulation on conversion of foreign currency into the yen abolished & Jun 1984 \\
\hline Money market certificate created & Apr 1985 \\
\hline Interest rates of large amount time-deposits liberalised & Oct 1985 \\
\hline Investment business law enacted & Nov 1986 \\
\hline Overseas deposits by residents liberalised & Jul 1989 \\
\hline Financial System Reform Act allowed banks to enter securities business & Apr 1993 \\
\hline Interest rates of Time deposits liberalised completely & Jun 1993 \\
\hline Interest rate on demand deposits liberalised (ex. current account) & Oct 1994 \\
\hline Restrictions on the number of a bank's new branches removed & Jun 1995 \\
\hline Regulation on deposit products relaxed & Oct. 1995 \\
\hline $\begin{array}{l}\text { 'Big Bang' reform announced - PM Hashimoto's idea of } \\
\text { 1/freedom } \\
\text { 2/fairness } \\
\text { 3/globalisation }\end{array}$ & Nov 1996 \\
\hline Ban on financial holding companies lifted & Dec 1997 \\
\hline $\begin{array}{l}\text { Amended FX and Foreign Trade Law making FX transactions free from } \\
\text { governmental authorisation }\end{array}$ & Apr 1998 \\
\hline Bank allowed to sell investment trust over-the-counter & Dec 1998 \\
\hline $\begin{array}{l}\text { Restriction on trust bank subsidiaries/securities company subsidiaries } \\
\text { abolished }\end{array}$ & Oct 1999 \\
\hline Bank allowed to issue straight bonds & Oct 1999 \\
\hline $\begin{array}{l}\text { Banks, securities companies to be allowed to enter insurance business } \\
\text { A new Financial Services Law to be enacted }\end{array}$ & End 2000 \\
\hline
\end{tabular}

Source: Japanese Banks 2000 (Zenginkyo, 2000)

Table 4. Korean Banking Liberalisation: post-1990

\begin{tabular}{|l|l|}
\hline Liberalisation measure & Date effective \\
\hline $\begin{array}{l}\text { Short-term interest rates and interest rates on time deposits with maturity over } \\
\text { 3 years liberalised }\end{array}$ & Nov 1991 \\
\hline Liberalised interest rates on time deposits with maturity over 2 years & Nov 1993 \\
\hline $\begin{array}{l}\text { Rates on strategic loans (BOK induced) were partially liberalised as the band } \\
\text { of preferred rates for this category was guided by the Government }\end{array}$ & Dec 1994 \\
\hline Liberalised interest rates on time deposits with maturity over 1 years & Dec 1994 \\
\hline Liberalised interest rates on time deposits with maturity over 6 months & Jul 1995 \\
\hline Fully liberalised interest rates on strategic loans & Jul 1995 \\
\hline $\begin{array}{l}\text { Liberalised interest rates on time deposits with maturity below 6 months } \\
\text { (completed } 4 \text { stage deregulation on interest rates: 1991-1997, earlier than } \\
\text { planned) }\end{array}$ & Nov 1995 \\
\hline $\begin{array}{l}\text { Allowing cross-sectoral entries within financial sector } \\
\text { Banks' securities business } \\
\text { Banks' insurance business }\end{array}$ & \\
\hline Branching restriction still remains & Early 1970s \\
\hline $\begin{array}{l}\text { Source: Korean Financial System (BOK, 1998) } \\
\text { N.B.: } \\
\text { 1) No further announcement of allowing banks to conduct insurance business as of Dec. } 2004 . \\
\text { 2) No indication for liberalising branching restriction as of Dec. 2004 }\end{array}$ & Not Applicable \\
\hline
\end{tabular}


Table 5. Description of Variables

\begin{tabular}{|c|c|c|}
\hline Variables & Type & Operational Definition \\
\hline \multicolumn{3}{|c|}{ Dependent Variables } \\
\hline $\mathrm{CNC}_{\mathrm{t}}$ & $\mathrm{C}$ & Banking concentration ratio indexed as $\ln \left[\mathrm{C}_{5 \mathrm{t}} / 1-\mathrm{C}_{5 \mathrm{t}}\right]$ \\
\hline $\mathrm{BCNC}_{\mathrm{t}}$ & $\mathrm{C}$ & Branch concentration ratio indexed as $\ln \left[\mathrm{BC}_{5 \mathrm{t}} / 1-\mathrm{BC}_{5 \mathrm{t}}\right]$ \\
\hline $\mathrm{AVB}_{\mathrm{t}}$ & $\mathrm{C}$ & Log of average branch network size \\
\hline $\mathrm{HHI}_{\mathrm{t}}$ & $\mathrm{C}$ & Banking concentration rescaled by $\mathrm{HHI} / 100$ \\
\hline $\mathrm{HHIN}_{\mathrm{t}}$ & $\mathrm{C}$ & Concentration in nationwide banking rescaled by HHIN/100 \\
\hline $\mathrm{HHIR}_{\mathrm{t}}$ & $\mathrm{C}$ & Concentration in regional banking rescaled by HHIR/100 \\
\hline \multicolumn{3}{|c|}{ Independent Variables } \\
\hline $\mathrm{MKS}_{\mathrm{t}}$ & $\mathrm{C}$ & Log of total deposit market size rescaled and deflated by GNP \\
\hline $\mathrm{IRD}_{\mathrm{t}-1}$ & $\mathrm{C}$ & Market average interest rates on deposits (1-2 year time \& savings) \\
\hline $\operatorname{IRL}_{\mathrm{t}-1}$ & $\mathrm{C}$ & Market average interest rates on loans ( 3 year fixed term) \\
\hline $\mathrm{ROD}_{\mathrm{t}-1}$ & $\mathrm{C}$ & Average return on deposits \\
\hline \multicolumn{3}{|c|}{ Lagged Dependent Variables } \\
\hline $\mathrm{CNC}_{\mathrm{t}-1}$ & $\mathrm{C}$ & 1 year lagged banking concentration ratio of $\mathrm{CNC}_{t}$ \\
\hline $\mathrm{BCNC}_{\mathrm{t}-1}$ & $\mathrm{C}$ & 1 year lagged branch concentration ration of $\mathrm{BCNC}_{t}$ \\
\hline $\mathrm{AVB}_{\mathrm{t}-2}$ & $\mathrm{C}$ & 2 year lagged average branch network size of $\mathrm{AVB}_{t}$ \\
\hline $\mathrm{HHI}_{\mathrm{t}-1}$ & $\mathrm{C}$ & 1 year lagged banking concentration of $\mathrm{HHI}_{\mathrm{t}}$ \\
\hline HHIN $_{\mathrm{t}-1}$ & $\mathrm{C}$ & 1 year lagged nationwide banking concentration of $\mathrm{HHIN}_{t}$ \\
\hline $\mathrm{HHIR}_{\mathrm{t}-1}$ & $\mathrm{C}$ & 1 year lagged regional banking concentration of $\mathrm{HHIR}_{\mathrm{t}}$ \\
\hline \multicolumn{3}{|c|}{ Deregulation Dummy Variables } \\
\hline $\mathrm{D}_{1 \mathrm{t}}$ & $\mathrm{L} / \mathrm{D}$ & $\begin{array}{l}\text { Deregulation on deposit interest rates measured between } 0 \text { and } 1: \\
1=\text { completely deregulated; } 0.5 \text { : halfway through in the deregulation } \\
\text { process; } 0=\text { fully regulated }\end{array}$ \\
\hline $\mathrm{D}_{2 \mathrm{t}}$ & $\mathrm{L} / \mathrm{D}$ & $\begin{array}{l}\text { Deregulation of branching restriction measured between } 0 \text { and } 1 \text { : } \\
1=\text { completely deregulated; } 0.5 \text { : halfway through in the deregulation } \\
\text { process; } 0=\text { fully regulated }\end{array}$ \\
\hline $\mathrm{D}_{3 \mathrm{t}}$ & $\mathrm{L} / \mathrm{D}$ & $\begin{array}{l}\text { Deregulation of cross-financial sector entry measured between } 0 \text { and } 1 \text { : } \\
1=\text { completely deregulated; } 0.5 \text { : halfway through in the deregulation } \\
\text { process; } 0=\text { fully regulated }\end{array}$ \\
\hline
\end{tabular}


Table 6. Structure of Japanese and Korean Banks by TSLS

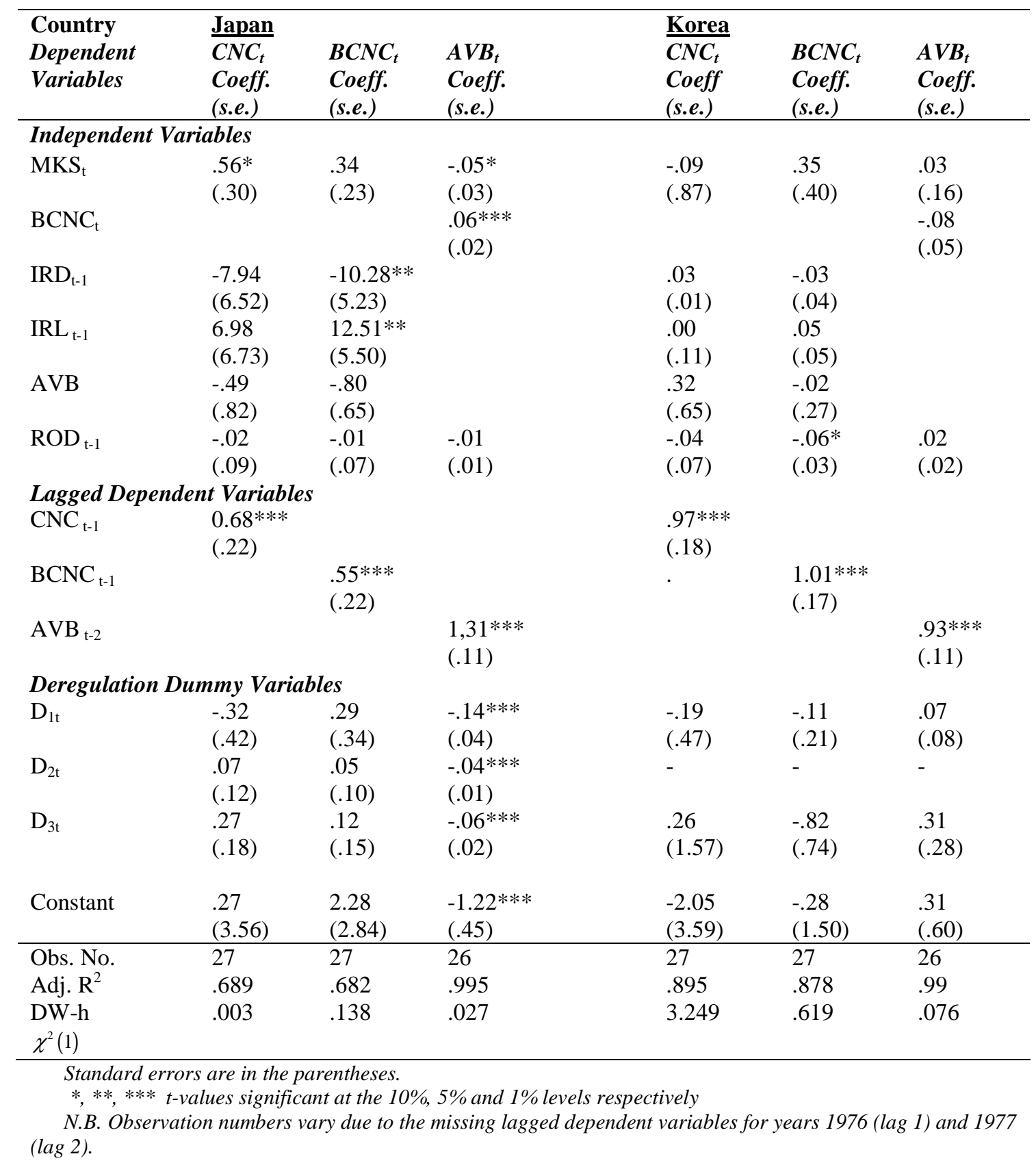


Table 7. Comparison between Nationwide and Regional Banking Structure

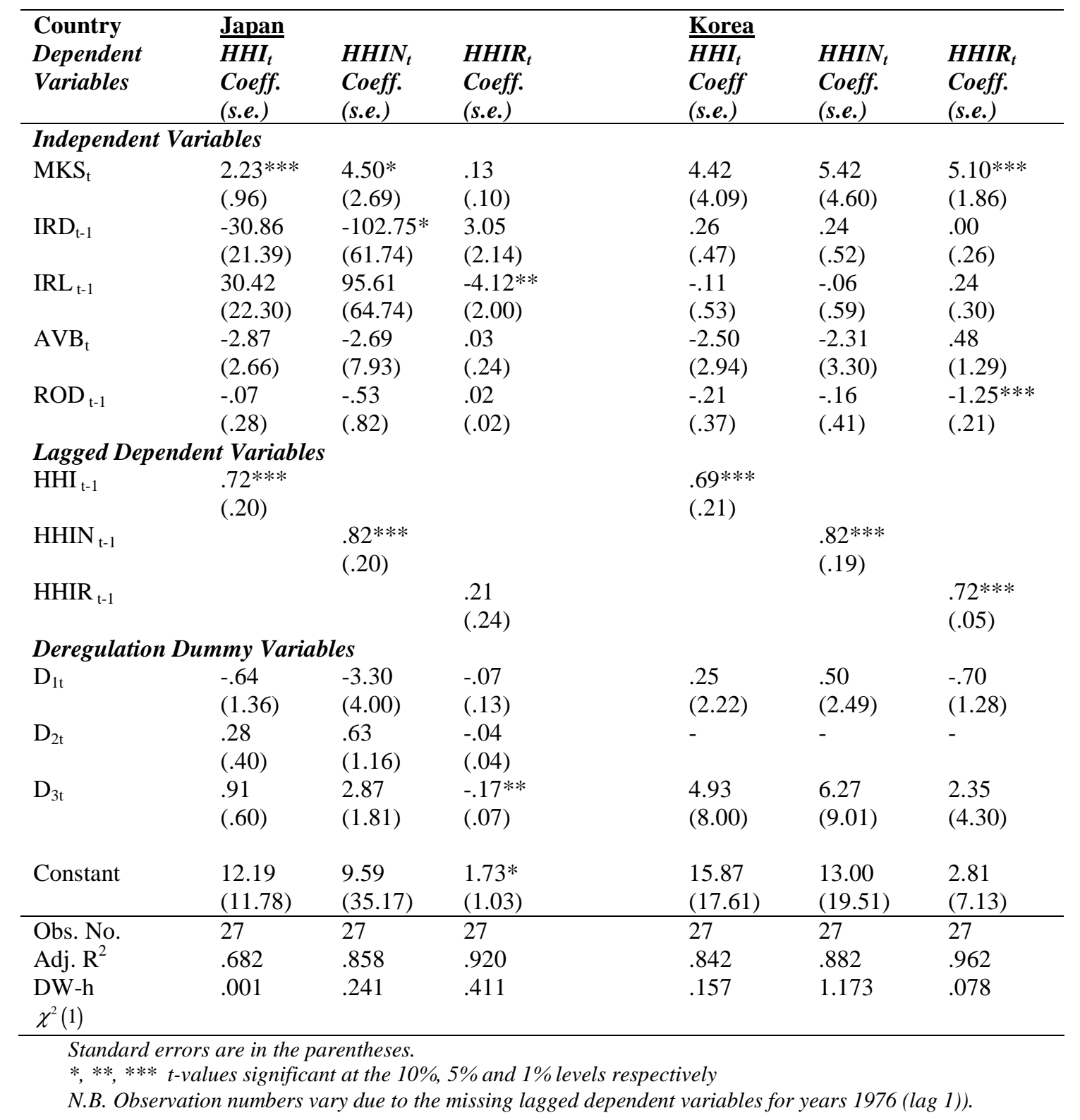


Figure 1. Japanese Commercial Banks

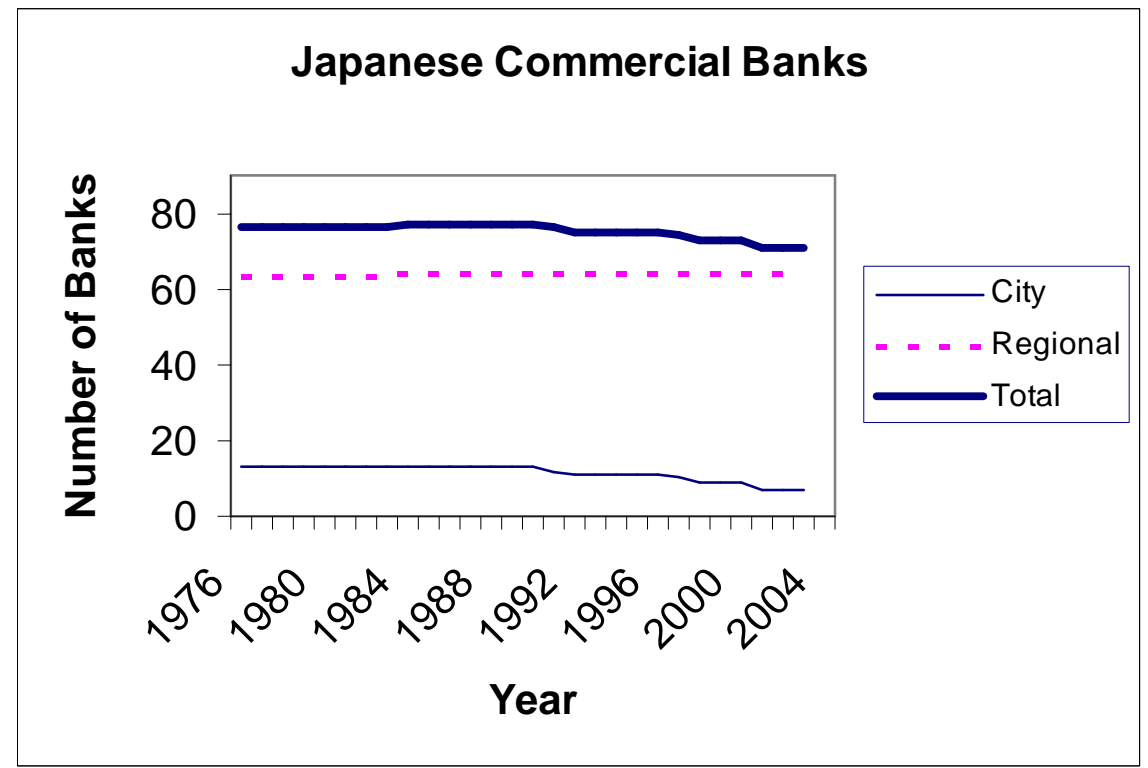

Source: Japanese Bankers Association(Zengynkyo)

Figure 2. Korean Commercial Banks

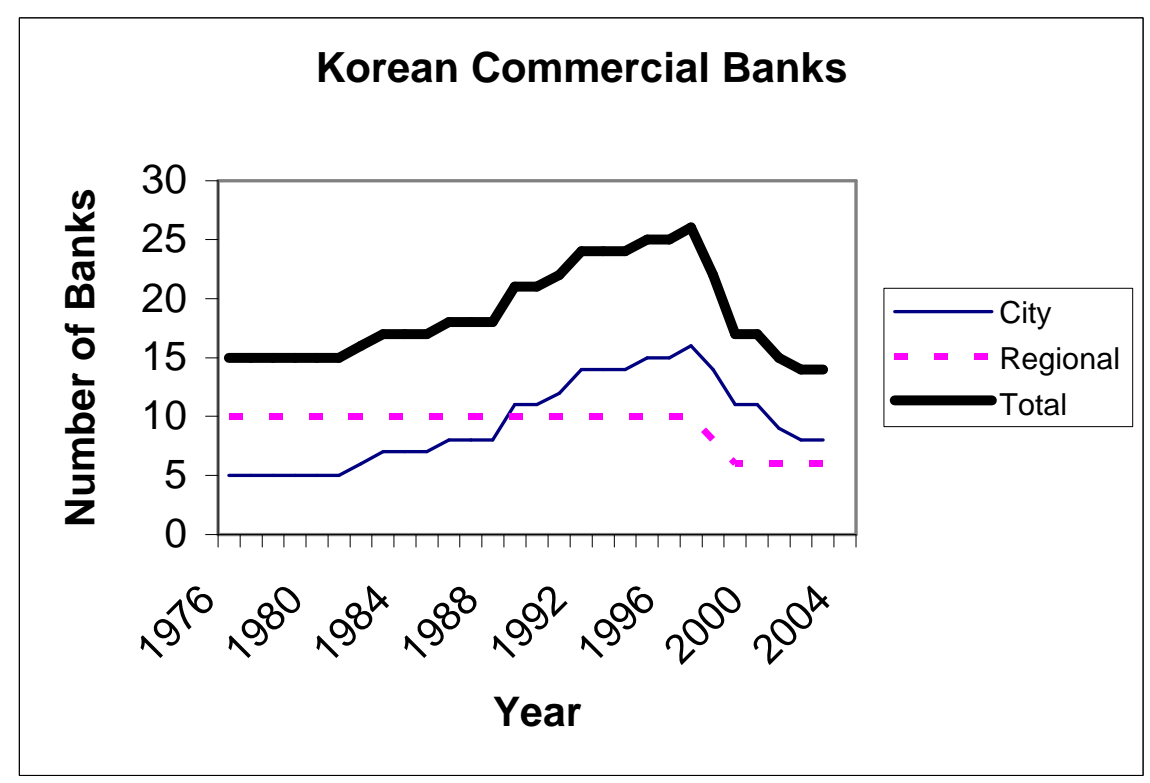

Source: Financial Supervisory Service (FSS) 
Figure 3. Banking Concentration $\left(\ln \left[\mathrm{C}_{5 t} /\left(1-C_{5 t}\right)\right]\right)$ in Korea and Japan

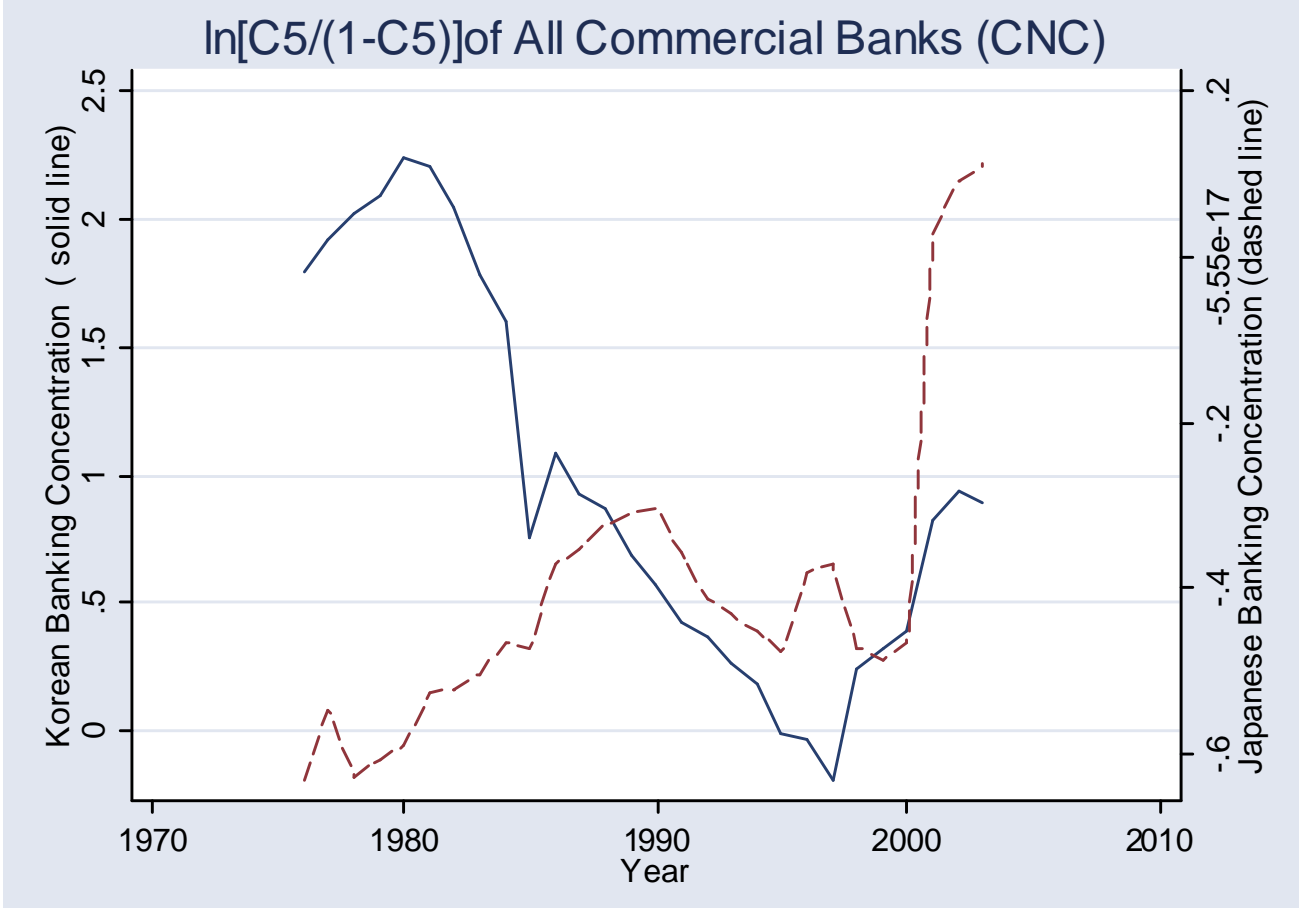

Figure 4. Banking Concentration $\left(\mathrm{HHI}_{t}\right)$ in Korea and Japan

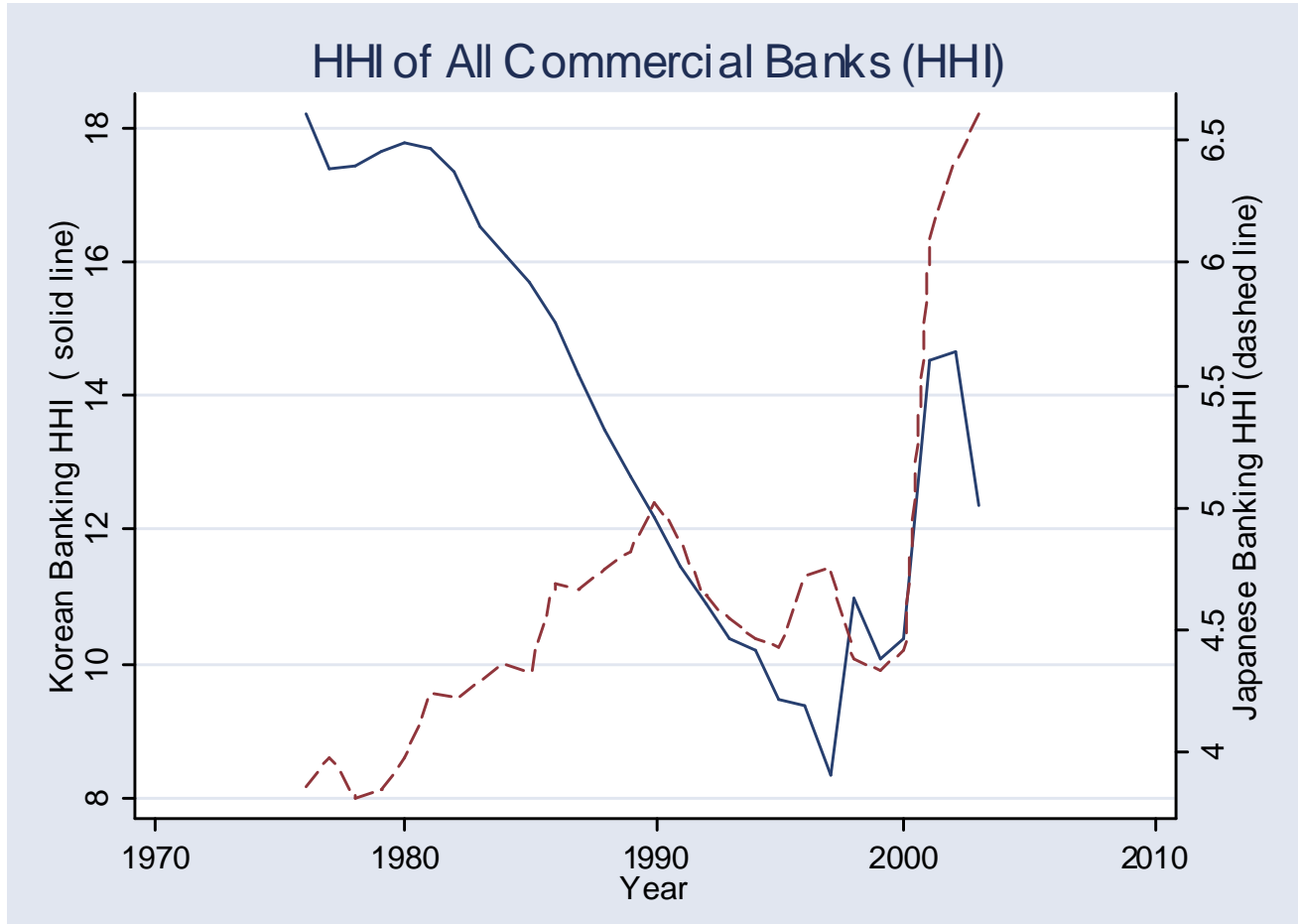


Figure 5. Nationwide Banking Concentration $\left(H H I N_{t}\right)$

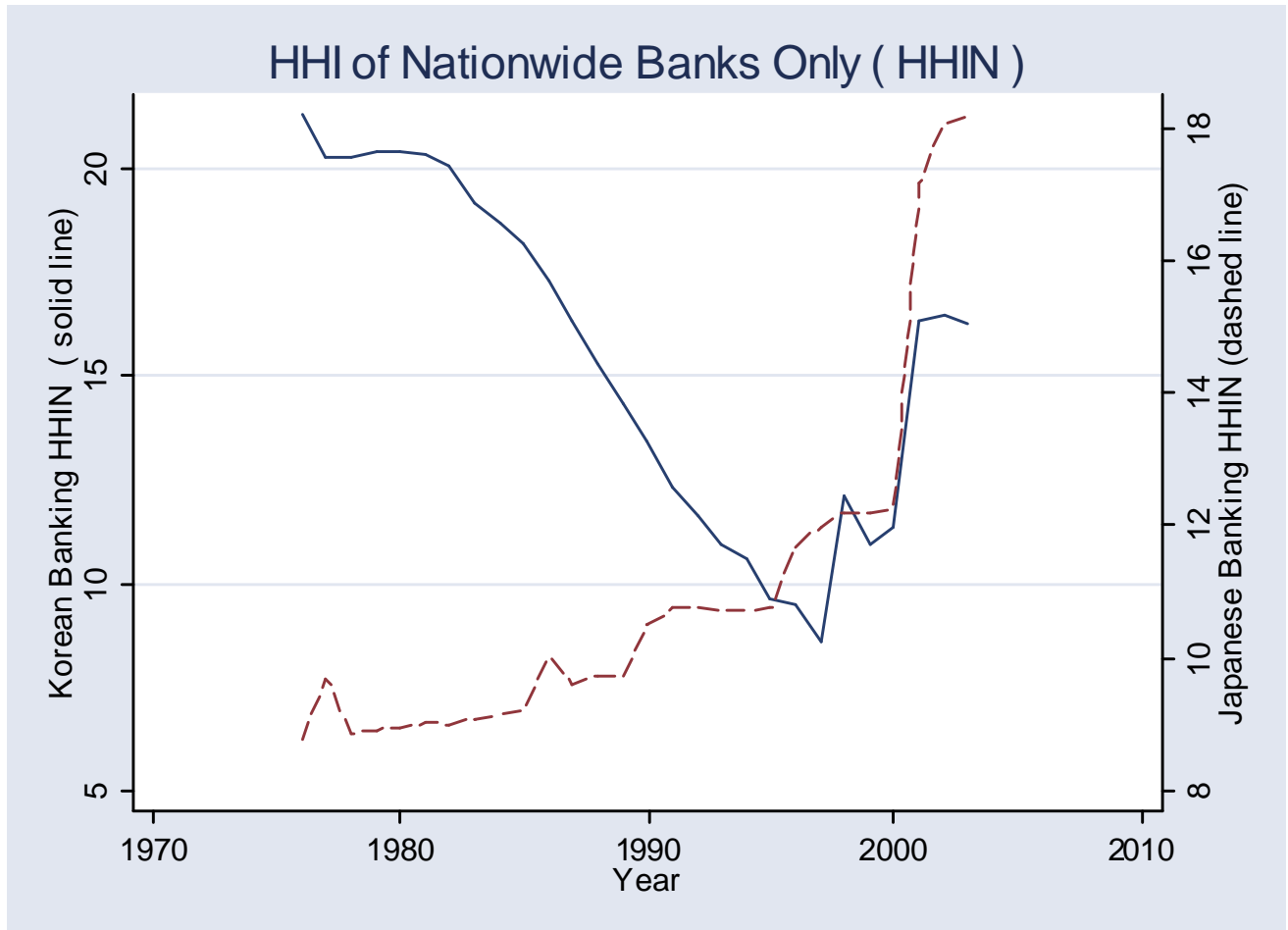

Figure 6. Regional Banking Concentration $\left(H H I R_{t}\right)$

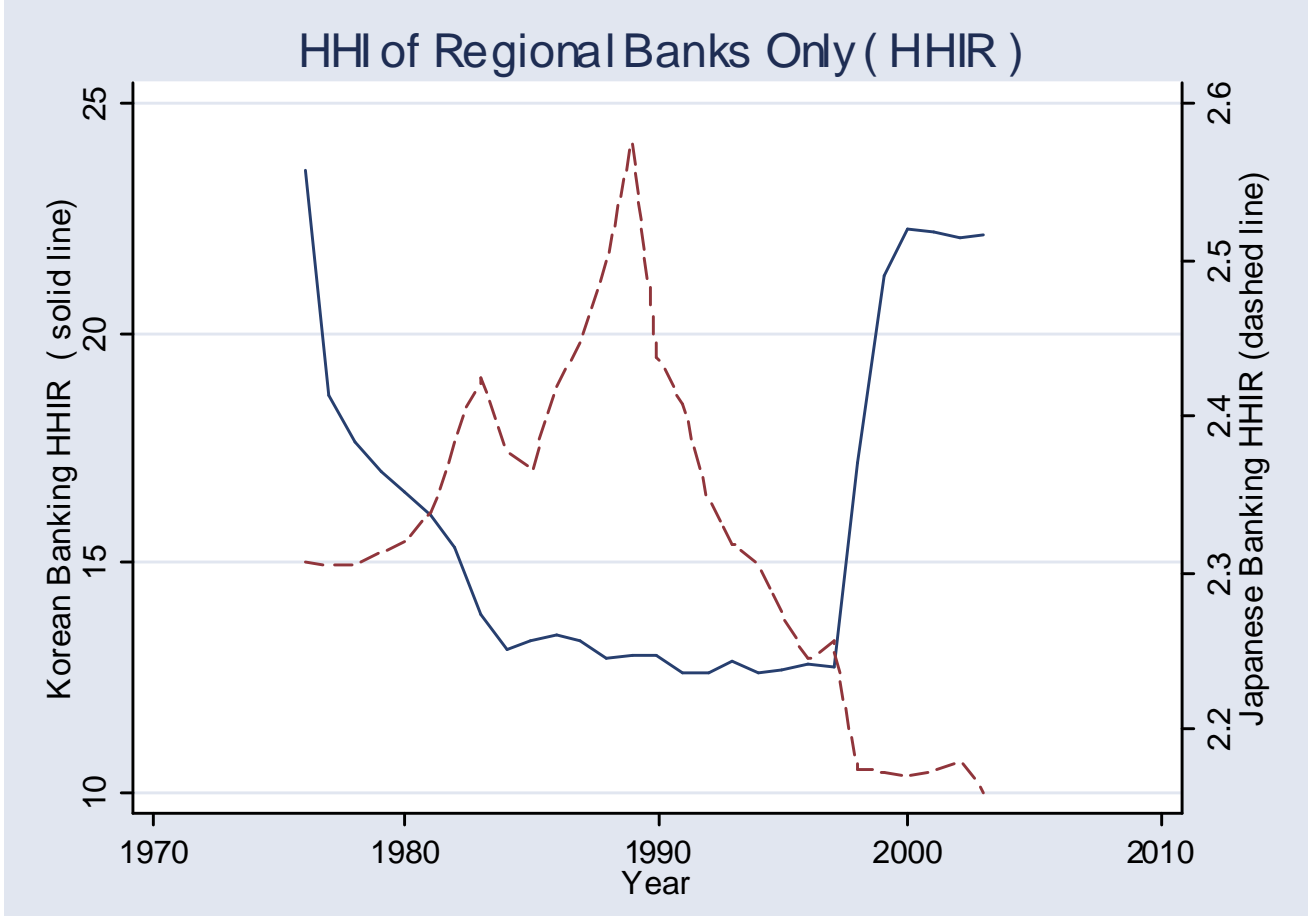


Figure 7. Branch Concentration $\left(B C N C_{t}\right)$

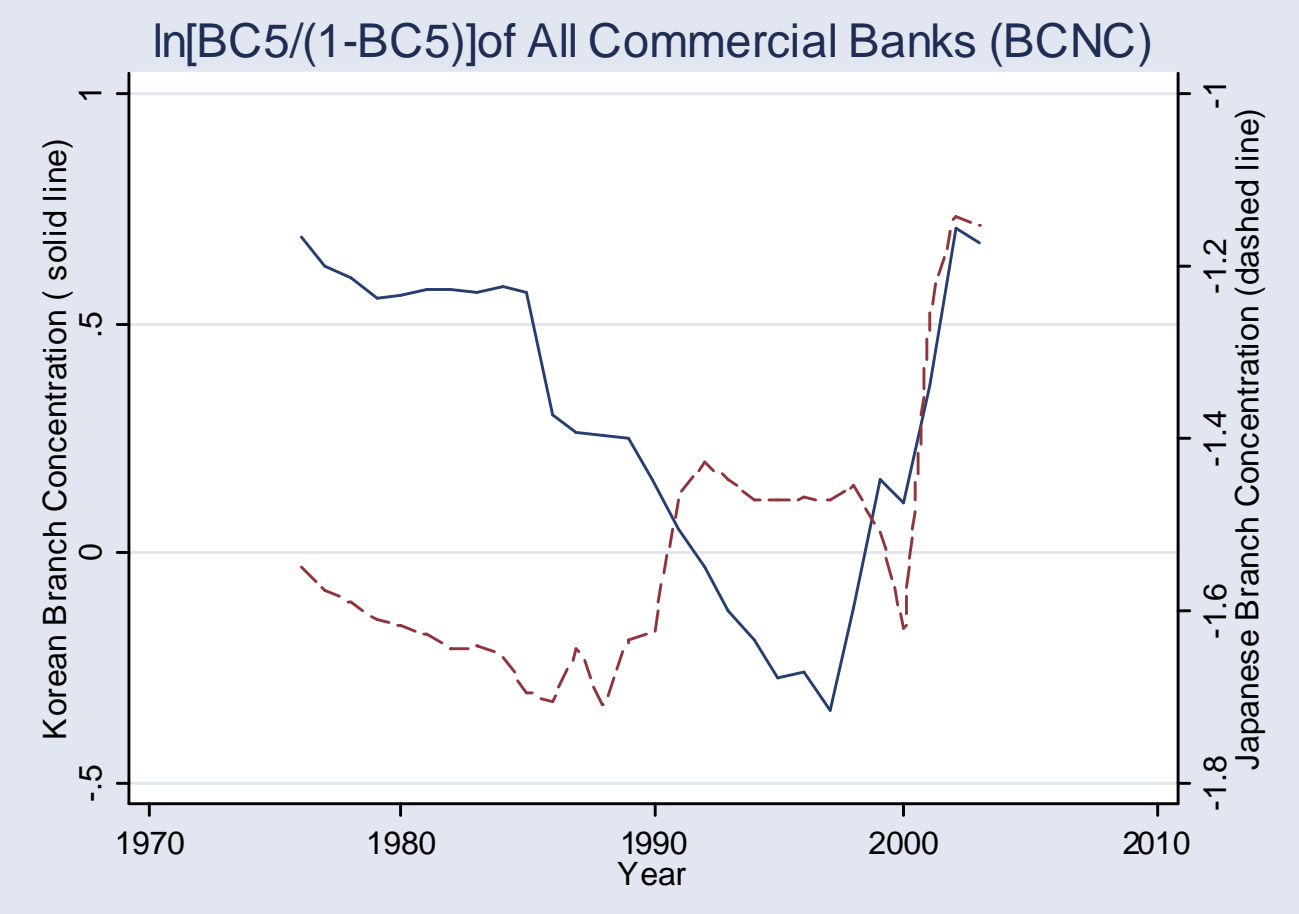

Figure 8. Average Branch Network $\left(A V B_{t}\right)$

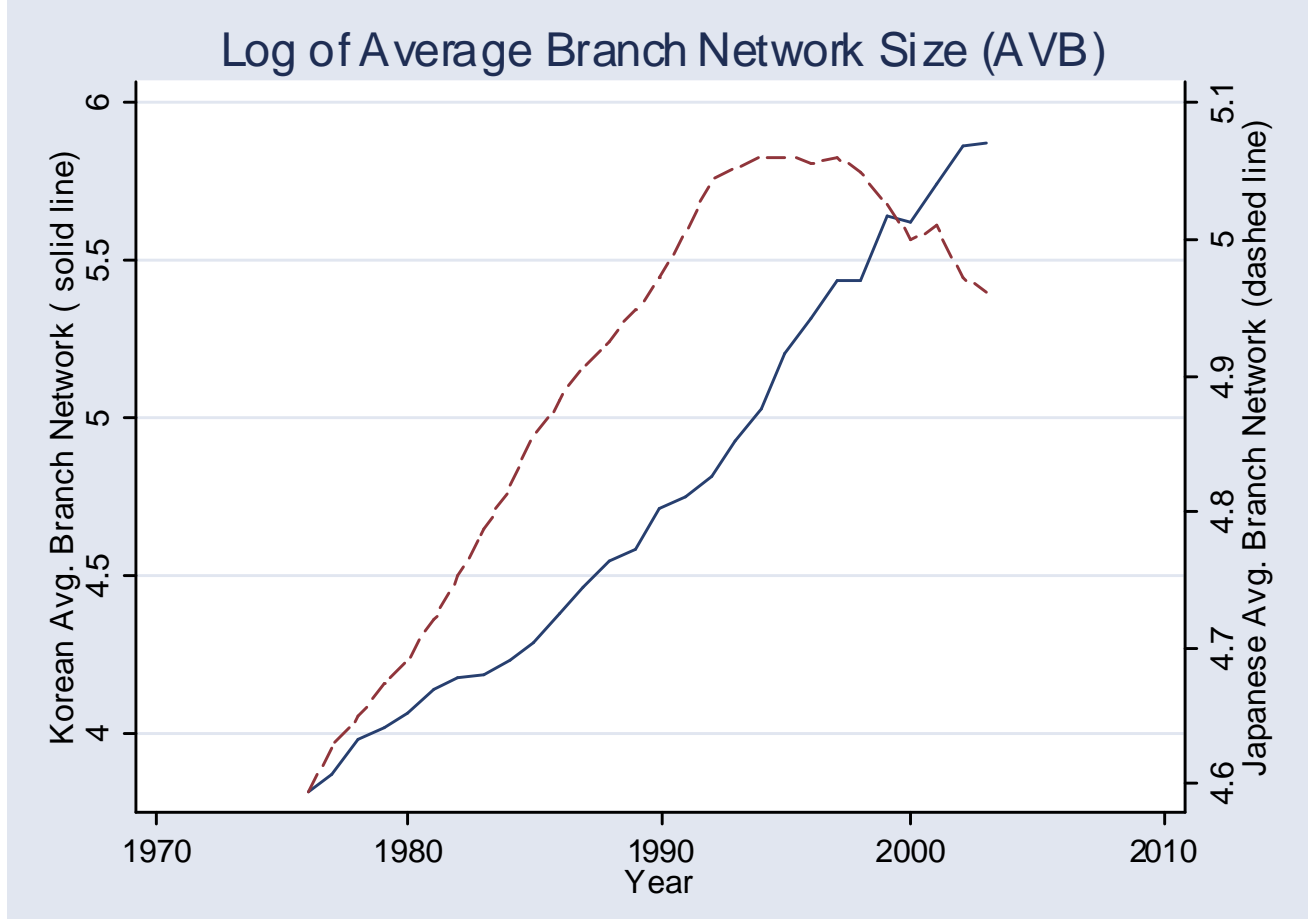


Figure 9. Interest Rates in Japan

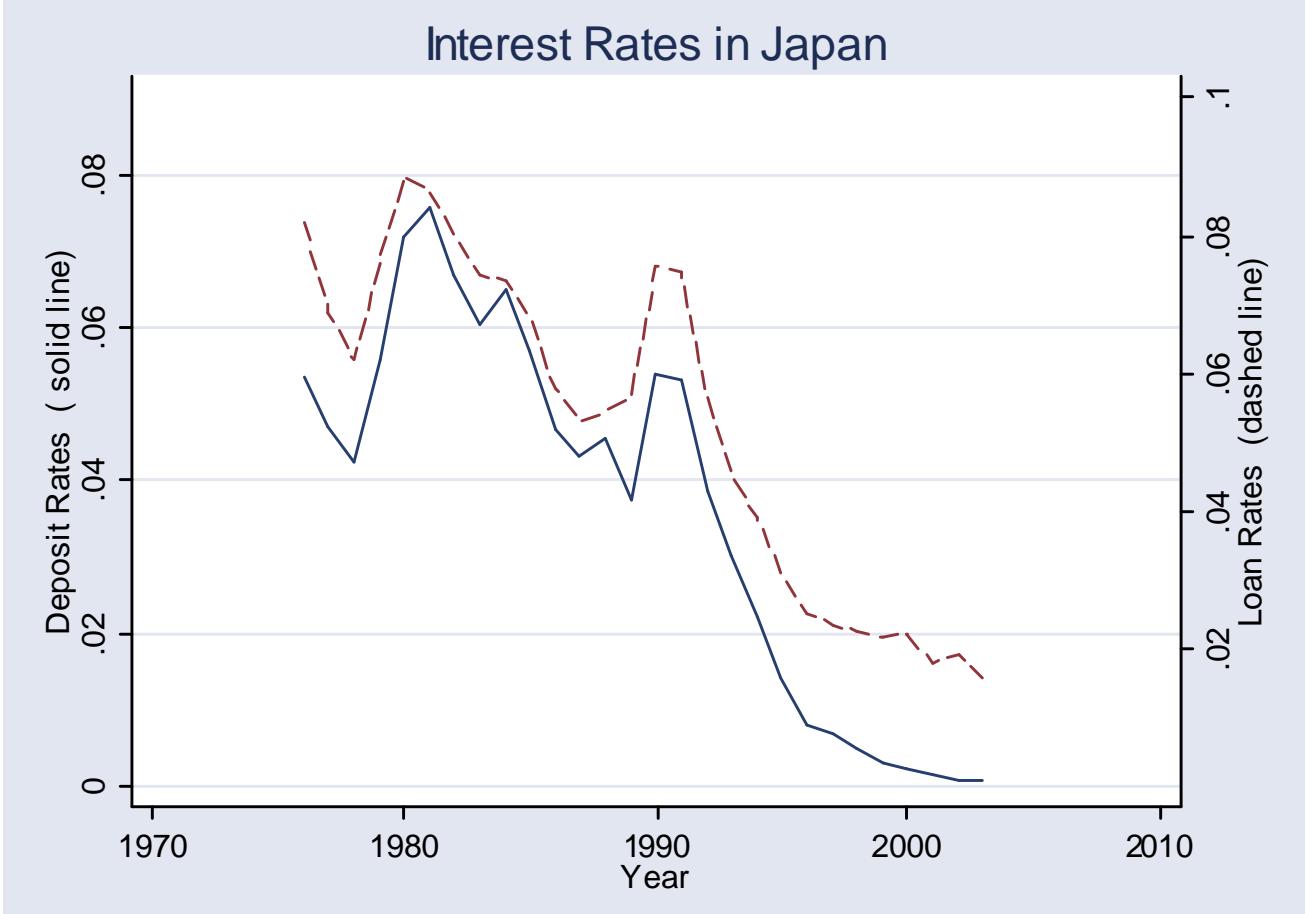

Figure 10. Banking Margins and Returns in Japan

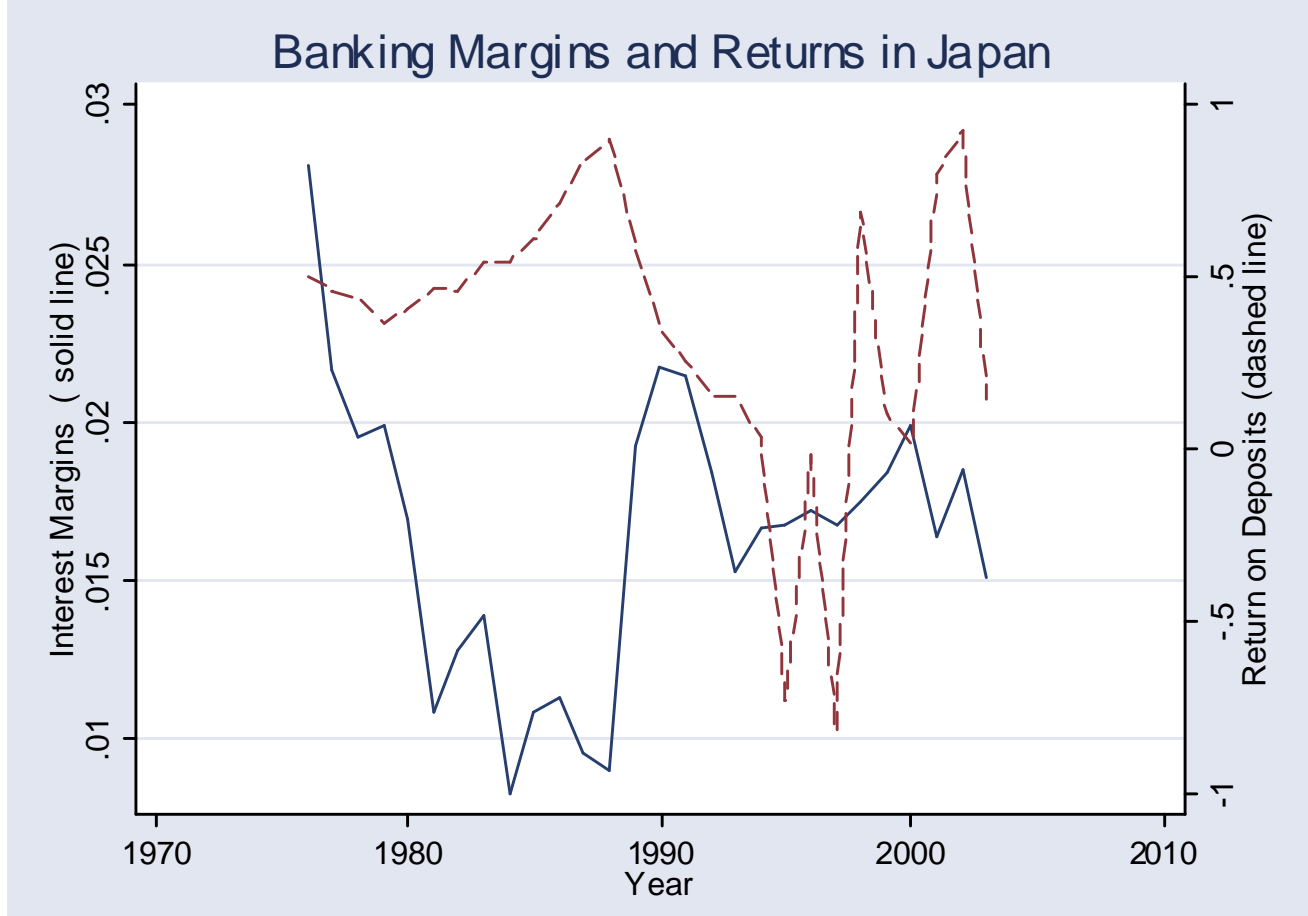


Figure 11. Interest Rates in Korea

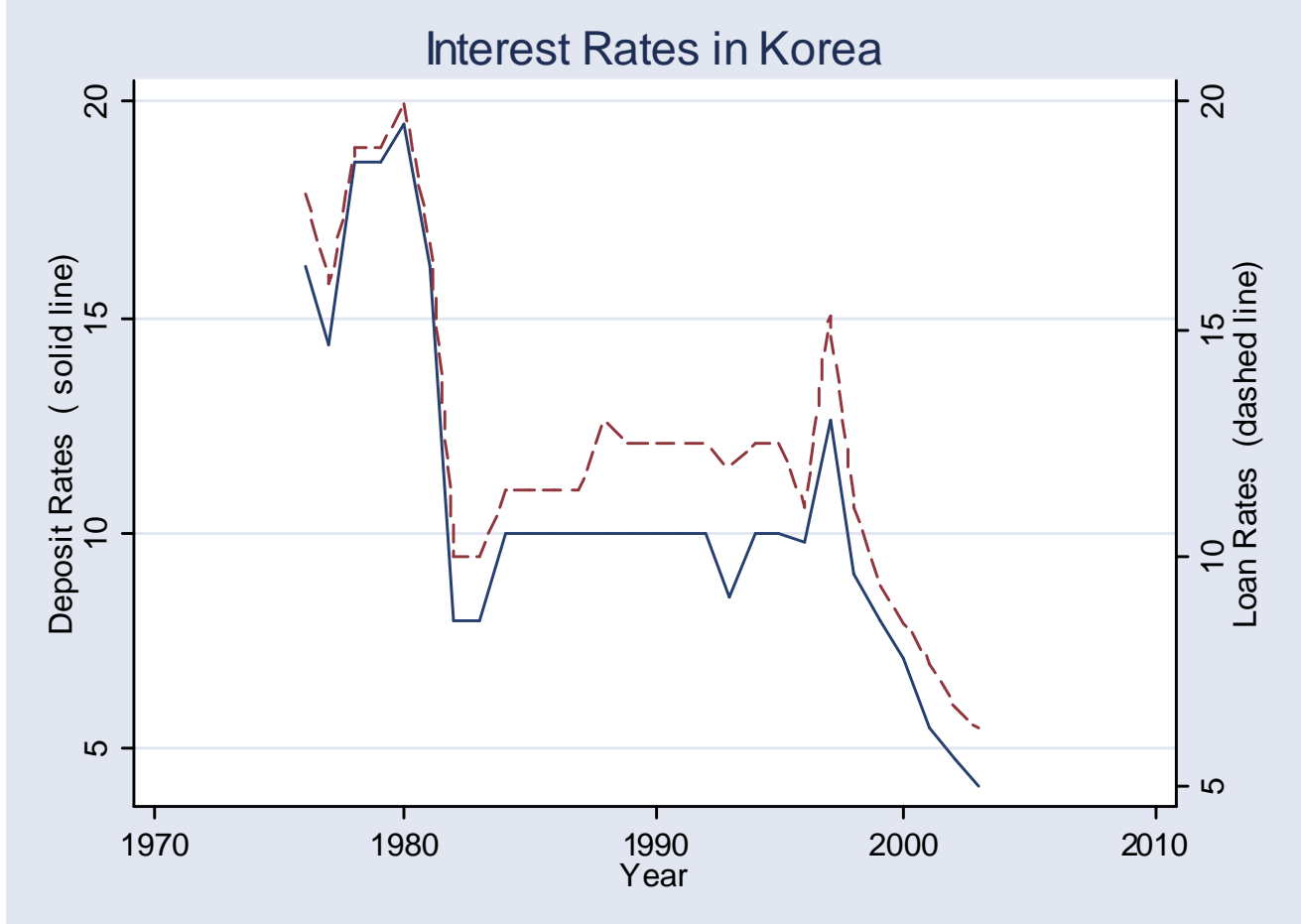

Figure 12. Banking Margins and Returns in Korea

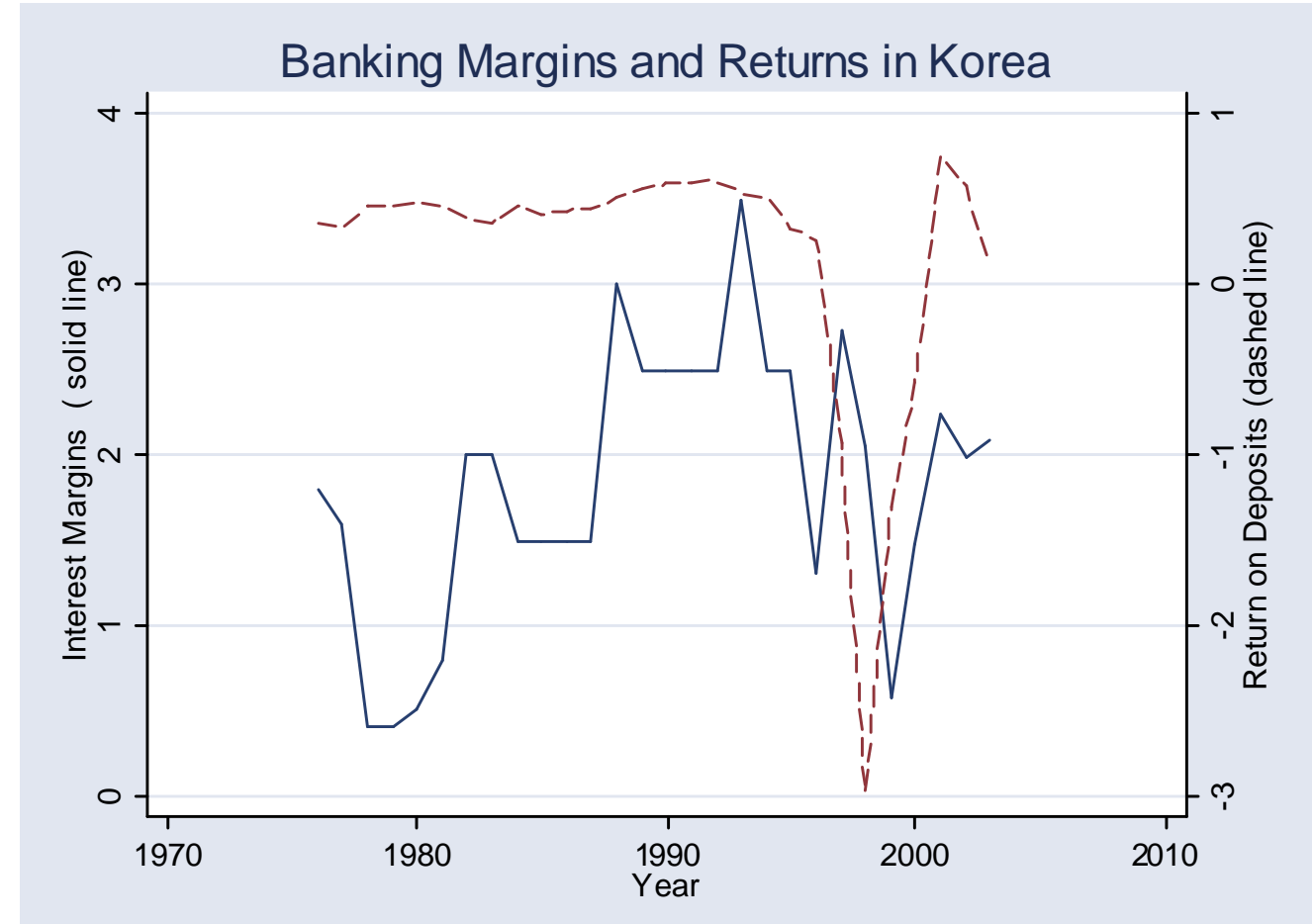


Figure 13. Deregulation on Deposit Interest Rates $\left(D_{1 t}\right)$

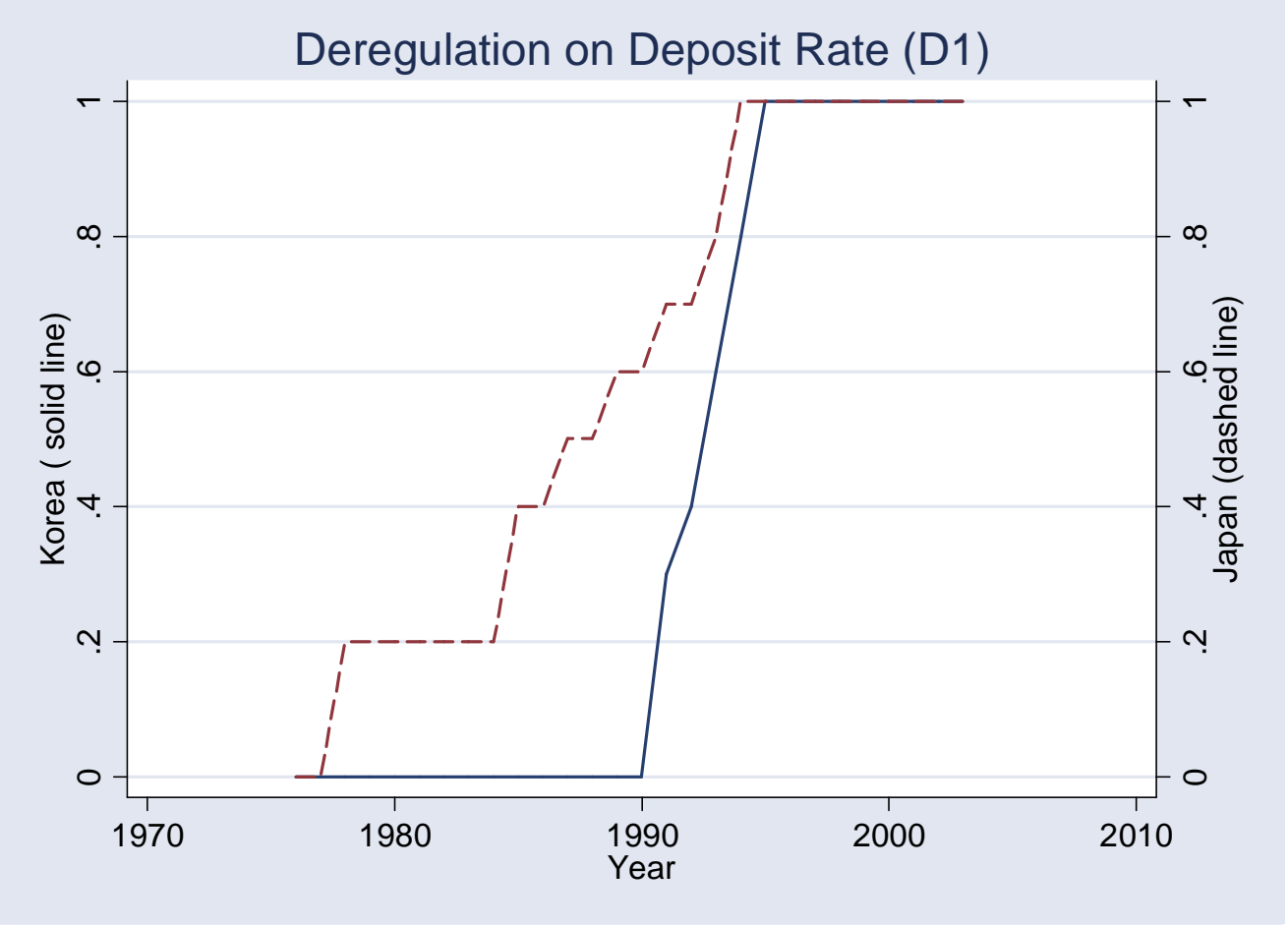

Figure 14. Deregulation of Branching Restriction $\left(D_{2 t}\right)$

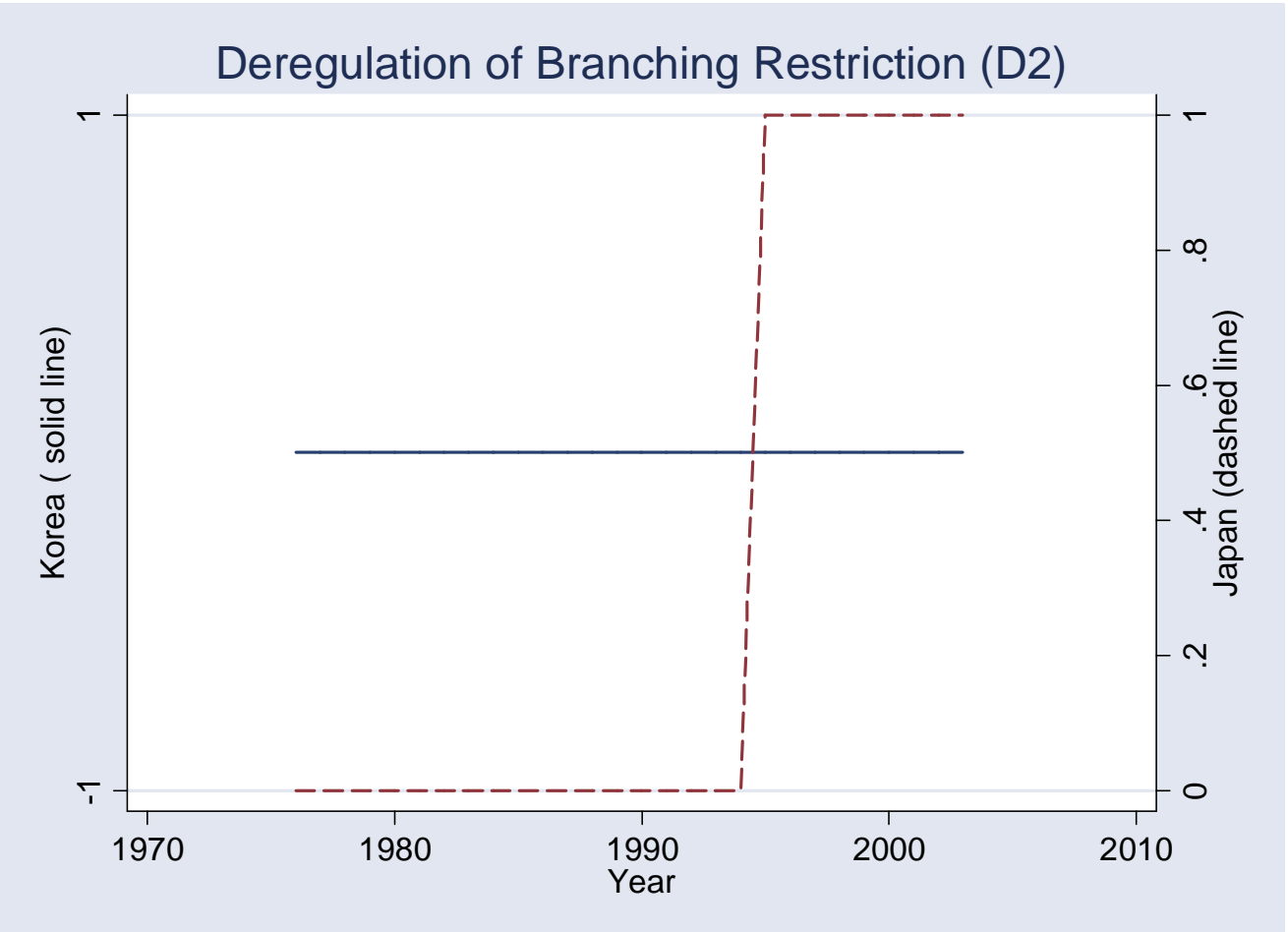


Figure 15. Deregulation of Cross-financial Sector Entry $\left(D_{3 t}\right)$

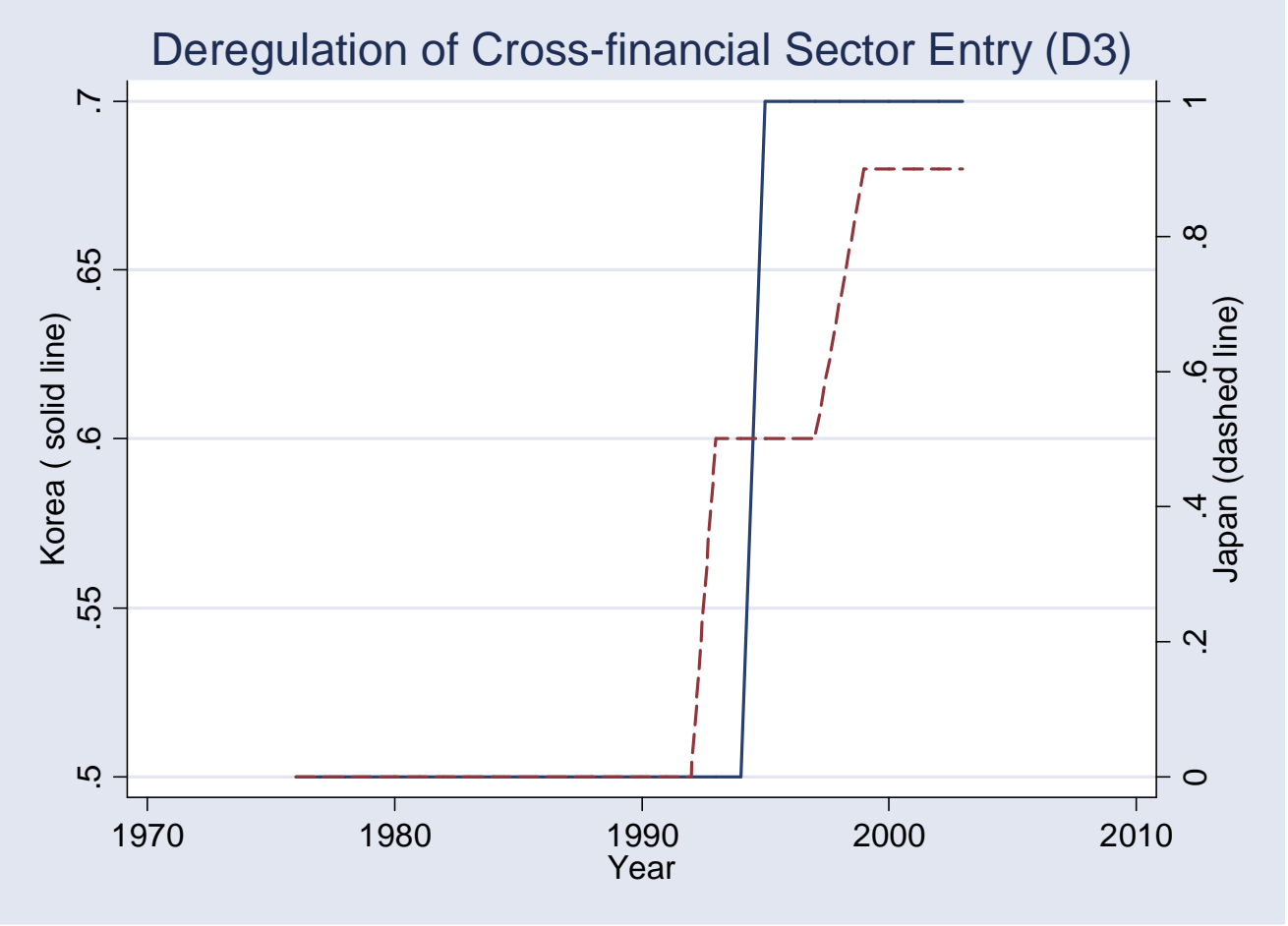




\section{References}

Agenor, P., Miller, M., Vines, D. and A. Weber (1999), The Financial Crisis - Causes, Contagion and Consequences, Cambridge Press.

Bain, J.S. (1951), "Relation of Profit Rate to Industry Concentration: American Manufacturing", 1936-1940. Quarterly Journal of Economics, Vol. 65, No.3, pp.293-324

Baltensperger E. (1972), "Economies of Scale, Firm Size, and Concentration in Banking", Journal of Money, Credit and Banking, Vol. 4, No. 3., pp. 467-488

Berger A.N. (1995), "The Profit-Structure Relationship in Banking - Test of the Market Power and Efficiency- Structure Hypotheses", Journal of Money, Credit and Banking, Vol. 27, No.2

Berger A.N. and T.H. Hannan (1989), "The Price-Concentration Relationship in Banking", The Review of Economics and Statistics, Vol. 71, No. 2., pp. 291-299

Calomiris, C.W. (1997), "Universal Banking and the Financing of Industrial Development", in Reforming Financial Systems: Historical Implications for Policy, edited by G. Carpio, Jr., and D. Vittas, pp.113-127., Cambridge University Press.

Castley, R (1997), Korea's Economic Miracle - The Crucial Role of Japan, MacMillan Press Ltd.

Cerasi, V. (1996), “A Model of Retail Banking Competition,” mimeo, London School of Economics.

Cerasi, V., Chizzolini, B. and M. Ivaldi (2002), "Branching and Competition in the European Banking Industry," Applied Economics, Vol.34, No.17, pp.2213-2225.

Cerasi, V. and S. Daltung (2000), "The Optimal Size of a Bank: Costs and Benefits of Diversification", European Economic Review, Vol.44, No.9, pp.1701-1726.

Chiappori, P., Perez-Castillo, D. and T. Verdier (1995), "Spatial Competition in the Banking system: Localization, Cross Subsidies and the regulation of Deposit Rates", European Economic Review, Vol. 39, No. 5., pp.889-918

Cho, S. (1994), The Dynamics of Korean Economic Development, Institute for International Economics

Clark J.A. (1988), "Economies of Scale and Scope at Depository Financial Institutions: A Review of the Literature", Economic Review, Federal Reserve Bank of Kansas City, Issue September, pp.16-33.

Cowling, K. (1976), "On the Theoretical Specification of Industrial Structure-Performance Relationship", European Economic Review, Vol. 8, pp.1-14

Cowling, K. and J. Cubbin (1972), "Hedonic Price Indexes for UK Cars", Economic Journal, Vol.82, pp. 963-978.

Cowling, K. and P.R. Tomlinson (2000), The Japanese Crisis - a Case of Strategic Failure, The Economic Journal, Vol.110, No. 464, pp.F358-F381

Dermine, J. (1986), "Deposit Rates, Credit Rates and Bank Capital: The Klein-Monti Model Revisited", Journal of Banking and Finance, Vol. 10, pp.99-114

Dewatripont, M. and E. Maskin (1995), "Credit and Efficiency in Centralised and Decentralised Economies,” Review of Economic Studies, Vol.62, Issue No.4, pp.541-555. 
Dewatripont, M. and J. Tirole (1993), "Efficient Governance Strucutre: Implications for Banking Regulation", in Capital Markets and Financial Intermediation, edited by C. Mayer and X. Vives, pp.12-45, Cambridge University Press.

Dewatripont, M. and J. Tirole (1994), The Prudential Regulation of Banks, MIT Press

Edwards F.R. (1964), "Concentration in Banking and Its Effect on Business Loan Rates", Review of Economics and Statistics, Vol. 46, No. 3, pp.294-300

Fama, E. (1985), “What's Different about Banks?” Journal of Monetary Economics, Vol.15, pp.2936.

Flechsig, T.G. (1965), "The Effect of Concentration on Bank Loan Rates (in Problems of Banking Structure)", Journal of Finance, Vol. 20, No. 2, Papers and Proceedings of the Twenty-Third Annual Meeting of the American Finance Association, Chicago, Illinois, December 28-30, 1964. (May, 1965), pp. 298-311

Freixas, X. and J.C. Rochet (1997), Microeconomics of Banking, MIT Press

Gehrig, T.H. (1993), "Intermediation in Search Markets", Journal of Economics and Management Strategy, Vol.2, No.1, pp.97-120.

Gehrig, T.H. (1996), "Natural Oligopoly and Customer Networks in Intermediated Markets", International Journal of Industrial Organization, Vol.14, pp.101-118.

Gilbert R.A. (1984), "Bank Market Structure and Competition: A Survey", Journal of Money, Credit and Banking, Vol. 16, No. 4, Part 2: Bank Market Studies, pp. 617- 645

Gordon, R. (1990), The Measurement of Durable Goods Prices, NBER, University of Chicago Press.

Greene, W.H.(2003), Econometric Analysis 5th edition, Prentice Hall

Hall, M.J.B. (1998), Financial Reform in Japan, Edward Elgar

Hannan, T.H. (1991), "Foundations of the Structure Conduct Performance Paradigm in Banking", Journal of Money, Credit and Banking, Vol. 23, No. 1, pp. 68-84

Heffernan, S. (1996), Modern Banking in Theory and Practice, John Wiley \& Sons

Hellman, T.F., Murdock K.C. and J.E. Stiglitz.(2000), “Liberalization, Moral Hazard in Banking, and Prudential Regulation: Are Capital Requirements Enough?", The American Economic Review, Vol. 90, No.1, pp.147-165

Ishii, K. (1997), The role of banking in Japan 1882-1973, Banking, Trade and Industry edited by Teichova, A., Kurgen-van Hentenryk, G., and Ziegler, D., Cambridge University Press.

Kalish, L.III and R.A. Gilbert (1973), "An Analysis of Efficiency of Scale and Organizational Form in Commercial Banking", Journal of Industrial Economics, Vol. 21, No. 3., pp. 293-307

Kaufman, G.G. (1992), Banking Structures in Major Countries, Kluwer Academic Publishers

Kim, D. (1999), “Bank restructuring in Korea”, BIS Policy papers No.6 - August 1999, pp.143-163

Klein M.A. (1971), “A Theory of the Banking Firm”, Journal of Money, Credit and Banking, Vol. 3, No. 2, Part 1, pp. 205-218 
Kolari, J. and A. Zardkoohi (1987), Bank Costs, Structure and Performance, Lexington Books

Macey, J.R. (2001), "Regulatory Competition in the US Federal System: Banking and Financial Services", in Regulatory Competition and Economic Integration Comparative Perspectives, edited by D. Esty, and D. Geradin, Oxford University Press.

Matutes, C. and X. Vives (2000), "Imperfect Competition, Risk Taking, and Regulation in Banking", European Economic Review, Vol.44, No.1, pp.1-34

Monti, M. (1972), "Deposit, Credit, and Interest Rate Determination under Alternative Bank Objectives," in Methmatical Methods in Investment and Finance, edited by G.P.Szego and K.Shell, North-Holland, Amsterdam.

Moore J. and R. Repullo (1988), "Subgame Perfect Implementation”, Econometrica, Vol. 56, No. 5. , pp. $1191-1220$

Neven, D. (1990), "Structural Adjustment in European Retail Banking: Some Views from Industrial Organisation", in Eurpoean Banking in the '90s, edited by J. Dermine, Basil Blackwell.

Novo-Peteiro, J.A. (2000), "New Technology, Information Reusability and Diversification: A Simple Model of a Banking Firm", Information Economics and Policy 12, pp.69-88

Porter R.C. (1960), “Open Market Operations Versus Reserve-Requirement Variation: Comment (in Notes and Memoranda)", The Economic Journal, Vol. 70, No. 279, pp. 618-620

Prager, R.A. and T.H. Hannan (1998), "Do Substantial Horizontal Mergers Generate Significant Price Effects? Evidence from the Banking Industry", The Journal of Industrial Economics, Vol. 46, No. 4, pp. 433-452

Repullo, R. (1995), “A Macroeconomic Model with Imperfect Competition in Banking”, Mimeo, Centro de Estudios Monetarios y Financieros (CEMFI).

Strickland, A.D. and L.W. Weiss (1976), "Advertising, Concentration, and Price-Cost Margins", The Journal of Political Economy, Vol. 84, Issue 5, pp.1109-1122

Sutton J. (1991), Sunk Costs and Market Structure, MIT Press

Sutton J. (1998), Technology and Market Structure, MIT Press

Teichova, A., Kurgan-Van Hentenryk, G. and D. Ziegler (1997), Banking, Trade and Industry, Cambridge University Press

Tirole, J. (1988), The Theory of Industrial Organisation, MIT press.

Tsutsui, W.M. (1999), Banking in Japan, Routledge.

Waterson, M. (1984), Economic Theory of the Industry, Cambridge University Press. 